\title{
Agroecosystem Service Capacity Index - A methodological approach
}

\author{
Horacio Augstburger ${ }_{1}^{*}$, Johanna Jacobi ${ }_{1}$, Gudrun Schwilch ${ }_{1}$, Stephan Rist ${ }_{1,2}$ \\ 1 University of Bern, Centre for Development and Environment (CDE), Switzerland \\ 2 University of Bern, Institute of Geography \& Centre for Development and Environment (CDE), Switzerland
}

\begin{abstract}
Sustainable food systems (FS) require providing food and other goods and services to humans satisfying food security, right to food, income, social justice and resilience, without degrading human health and hiving high environmental performance. The environmental performance of FS can be evaluated using Life Cycle Assessment. However, research on the impact that FS activities, e.g. crop production have on the capacity of farm-based agroecosystems to provide goods and services to humans is still incipient. Our underlying aim was to understand how FS impact on the provision of agroecosystem services and how this relates to the environmental performance of FS, as a basis for supporting decision-making on how to make FS more sustainable. We propose the Agroecosystem Service Capacity (ASC) as a method for assessing farmbased agroecosystem services, it builds on the Ecosystem Service Matrix by Burkhard et al. (2009) and assesses land cover classes against 20 agroecosystem services. The method was applied to eighteen farmbased agroecosystems in Bolivia and Kenya. Here we present two examples for exploring its potentials and limitations. The ASC operates on the basis of land cover class units and permits the calculation of an aggregate ASC-index for farm-based agroecosystems forming part of a specific FS.
\end{abstract}

\section{Keywords:}

Agroecosystems, agroecosystem services, land cover classes, food system

*Corresponding author. Email: horacio.augstburger@cde.unibe.ch

(C) The Authors. 2018. Landscape Online. This is an Open Access article distributed under the terms of the Creative Commons Attribution License (http://creativecommons.org/licenses/by/4.0), which permits unrestricted use, distribution, and reproduction in any medium, provided the original work is properly cited. 


\section{Introduction}

Humans have modified the Earth's surface to such an extent that some refer to the current geological epoch as the Anthropocene, thereby equating the importance of human impact on Earth withpast geophysical processes (Crutzen \& Stoermer 2011; Steffen et al. 2011). Agricultural production and related activities - from provision of food products to consumption and waste - are an important factor of the Anthropocene. Together, these activities have modified approximately $40 \%$ of the Earth's surface (Foley et al. 2005). Foley et al. (2011) suggest that agricultural activities are the major force driving the environment beyond the "planetary boundaries" as defined by Rockstrom et al. (2009). Even though agriculture has shaped the Earth's crust, the number of hungry people has been on the rise again since 2014, reaching anestimated 815 million in 2016 (FAO et al. 2017). Moreover, nutritional outcomes are poor and the environmental impacts related to food production are severe, mainly regarding land cover change and the degradation of ecosystem services (Ericksen 2008; Therond et al. 2017). This situation led the United Nations Special Rapporteur on the right to food to conclude that "[ $t]$ he food systems we have inherited from the twentieth century have failed" (Schutter 2014, p. 4). Food systems are major contributors to the most critical problems humans face; but they can also play a major role in solving these problems (IAASTD, 2009).

The pressure on agricultural land to produce biomass while reducing environmental impacts is on the rise (Fischer etal.2008; Duru et al. 2015). In the first half of the twentieth century, agriculture was characterized by crop sequence diversity, management of soil organic matter, and biological processes. Since the 1950s, and particularly since the "Green revolution" (from the 1960ies onwards), external chemical inputs have replaced, or reduced many ecosystem services (Therond et al. 2017). This predominant productivist agricultural paradigm must be fundamentally transformed (Foley et al. 2011; Duru et al. 2015; Fouilleux et al. 2017). The need for a paradigm shift is also fueled by ongoing debates about landscape management, in which authors incerasingly suggest to move from land sparing (intensifying land use on the one hand and spare other land for conservation on the other hand) towards the more integrative approach of land sharing (maintaining a coherent and diverse landscape matrix with moderately intense use in order to preserve biodiversity throughout agricultural practice) (Green et al. 2005; Phalan et al. 2011; Fischer et al. 2014; de la VegaLeinert \& Clausing 2016). Instead of viewing land sharing and land sparing as mutually exclusive land management options, it should be recognized that both offer different and sometimes complementary advantages (Fischer et al. 2008; de la Vega-Leinert 2014; Lee et al. 2014). A more recent approach to landscape management in this line of thought is landscape multifunctionality, which aims at designing landscapes that serve multiple purposes,including, for example, carbon storage, flood regulation, and biodiversity conservation (Erik et al. 2009; Manning et al. 2018). Food system activities are multifunctional: They produce food, feed, fibre, fuel, and other goods and also have a major influence on other essential ecosystem services, such as water supply and carbon sequestration (IAASTD, 2009). Food production is a crucial ecosystem service provided by agroecosystems (Power 2010). However, agroecosystems must do more than just deliver provisioning services such as food (Zhang et al. 2007; Lescourret et al. 2015). They must also provide other services, such as soil nutrient recycling, microclimate regulation, biotic heterogeneity and regulation of hydrological processes (Altieri 1999; Porter et al. 2009).

This means considering that agricultural production of food or feed - on farms, by communities, or by corporations - is part of agroecosystems, which also produce coupled agroecosystem services. These agroecosystem services are of fundamental importance for the long-term sustainability of food systems and the complex socio-ecological systems of which they are part (Biel 2016). There is growing evidence that future agricultural landscapes need to reduce harmful inputs of agrochemicals into the environment and offer cultural services that support the sustainability of food systems (Peano et al. 2014; 
Šūmane et al. 2018). Yet, according to Horlings and Marsden (2011, p. 450) this "requires a more radical move and debate among scientists about fostering a new type of (multi-scalar) agri-food eco-economy". Taking this more comprehensive approach means looking at agroecosystems and the way they are related to different ways of producing, processing, retailing, and consuming food. Such a food system approach must therefore be able to identify how different food systems, beyond providing food or feed, are inherently linked to the provision of agroecosystem services, expressed e.g. in nutrient cycling, food and feed, water purification, and cultural heritage (Altieri 1983; Horlings \& Marsden 2011; Lescourret et al. 2015).

The potential of landscapes to offer multiple benefits by agroecosystem services to society beyond commodity production has received increasing attention in research and policy (de Groot et al. 2010; Mastrangelo et al. 2014; Manning et al. 2018). However, assesseing the capacities of agricultural landcapes to provide agroecosystem services remains a challenge. Perfecto et al. (2009) advocate an agricultural paradigm that integrates agriculture and conservation in high-quality landscape patches where objectives of agricultural production and environmental conservation can co-exist. While this paradigm offersan interesting perspective, it lacks methodological guidelines on how to assess the quality of such landscapes. In this regard, Burkhard et al $(2009 ; 2014)$ take an approach of studying landscapes' capacities to provide ecosystem services. Their method includes an ecosystem service matrix as a basis for assessing the capacity of each land cover class in the ecosystem to provide ecosystem services. Burkhard et al. (2009) use the land cover classes developed by the European CORINE project and rely on existing landscape data. We have taken this method a step further by adapting it for use in the context of food systems in the global South and with data available on farms.

Inspired by the paradigm shift proposed by Perfecto et al. (2009) and building on the methodological approach of Burkhard et al. (2009), in this article we present a novel multiscale methodological approach that we refer to as Agroecosystem Service Capacity (ASC). The method is based on identifying the land cover classes of farm - based agroecosystems related to different food systems, as well as the types and numbers of agroecosystem services they provide. The types and numbers of agroecosystem services across all land cover classes of a given farm-based agroecosystem are aggregated in the ASC Index, which makes it possible to compare the capacities of different food systems to provide agroecosystem services. The potentials and limitations of this methodological approach are illustrated and discussed on the basis of empirical results from Kenya and Bolivia. Šūmane et al. (2018) argue that transition towards more sustainable agriculture requires a new knowledge base that includes new contents, new forms of knowledge, and new learning processes. The ASC approach contributes to such a new knowledge base by generating new forms of knowledge about agroecosystems that can ultimately help to advance transformations towards more sustainable food systems.

\section{Background concepts for agroecosystem capacity assessment}

\subsection{Ecosystems and agroecosystems}

The natural living world can be seen as a nested hierarchy of systems (organisms-populationcommunity-ecosystem-biome-biosphere), each of which has its own system behaviour and a more or less clearly defined boundary (Conway 1985). Ecosystems have been defined in the Convention of Biological Diversity (1992, p. 3) as "a dynamic complex of plant, animals and microorganism's communities and their non-living environment interacting as a functional unit". Ecosystems have patternsof natural processes of nutrient cycling, population regulation, dynamic equilibrium, and flows of energy (Altieri 1983). De Groot et al. (2002, p. 294) define ecosystem functions as "the capacity of natural processes and components to provide goods and services that satisfy human 
needs, directly or indirectly". Ecosystem services are defined by the Millennium Ecosystem Assessment (2005) as benefits people obtain from ecosystems, including provisioning services, regulating services, supporting services, and cultural services.

Agricultural activities take place in parts of ecosystems that are transformed into agroecosystems. The original natural equilibrium of the ecosystem is altered by a combination of ecological and socioeconomic activities (Altieri 1983) in order to produce food, feed, fibre, or other goods. Although human alterations of ecosystems for agricultural production might be severe, the natural processesof ecosystems still operate as part of agroecosystems. The magnitude of the differences between ecosystems and agroecosystems depends on management decisions and levels of ecosystem modification (Altieri 1983).

Agroecosystems can be further conceptualized as networks of land cover classes within a site or integrated region. They result from land management decisions taken by land users (Gliessman 2007). Beyond production, land use decisions also consider the availability, cost, and properties of inputs - e.g. fertilizers, pesticides, seeds, machinery, or credits-as well as the demand of actors in charge of processing, selling, or consuming the food to be produced. This means that agroecosystems - and their managers become part of food systems, which shape the type of food production with their specific characteristics of input provision, processing, selling, consuming, and treating the waste that results throughout the whole processes.

Food systems therefore influence land use and land management decisions, which in turn result in specific environmental outcomes related to complex natural interactions in the soil, the atmosphere, plants, animals, and microorganisms (Altieri 1983, 1999). Food systems and related land use decisions thus play an important role in the creation of cultural landscapes, which, according to the respective types of land use, have specific capacities to provide agroecosystem services. Agroecosystem services are commonly defined as specific combinations of provisioning, regulating / maintenance, and cultural goods and services (Kyösti \& Olli 2013; Wiggering et al. 2016) (see Fig. 1).

The behaviour of agroecosystems can be described by four system properties - productivity, stability, sustainability, and equitability - which can also be used as indicators of their performance (Conway 1985). López-ridaura et al. (2005) provide an overview of attributes used to define sustainability in peasants' natural resource management systems, concluding that the five most-used indicators are productivity, stability, equability, adaptability and resilience. Therond et al. (2017) developed a new analytical framework to characterize farming systems based on two main characteristics, which they represent graphically on two axes: The vertical axis describe the shares of agricultural production derived from ecosystem services and from external anthropogenic inputs. The horizontal axis describe the main features of socio-economic contexts that determine the territorial embeddedness and economic relationships and behaviours centred on global market prices. The challenge in creating sustainable agroecosystems is to achieve natural ecosystem-like characteristics in agroecosystems (environmental sustainability) while maintaining productivity (economic sustainability) (Gliessman 2007) and equitable social outcomes (social sustainability).

Ecosystems are usually large units, which makes it difficult to relate them - and their ecological services - directly to food systems. Agroecosystems, understood here as a specific area in which the natural ecosystem is modified for agricultural purposes, are hence more directly related to food systems. Food systems are interdependent networks of actors that are connected by the flow of goods and services to satisfy local and global food needs (Colonna et al. 2013). Fundamental components of food systems are commonly rural spaces in which agricultural production takes place. Decisions by actors running family, community, or corporationbased food production reflect the specific features of the value chains of which they are part. This relates to the inputs available (fertilizers, pesticides, 
seeds, machinery, credits, knowledge, etc.) and the requirements of food processing, trading, selling, and consumers(Rist \& Jacobi 2015). The combination of these aspects translates into management decisions that are expressed in different patterns of land cover classes in agroecosystems. From there, we develop the idea that if agroecosystems represent the part of ecosystems most directly influenced by food systems, determining agroecosystem services constitutes an important indicator for assessing one dimension of the environmental performance of food systems. In our approach, we draw on the wide field of literature about how to determine ecosystem services and adapt these methods to the agricultural context, to identify what we call "agroecosystem services". Agroecosystemservices are those ecological services provided by the parts of an ecosystem that are most directly related to specific food system activities.

Ecosystem service assessment and mapping has increased in importance and become a useful tool in science, policy, and decision-making (Malinga et al. 2015). There is a large body of literature on methodologies to assessor value ecosystem services. Some are developed to assess ecosystem services at large scales, e.g. García-Nieto et al. (2013) for southeast Spain. Others depend on secondary data for their assessment, like Petter et al. (2013). Still others use primary data at the local scale, such as Sinare et al. (2016), or, as Carvalheiro et al. (2010), focus in depth on one regulating service (e.g. pollination). A review by Malinga et al. (2015) shows that most studies focus on regulating ecosystem services and refer to intermediate spatial scales (municipal scale or larger), and less to the village or farmlevel.

Various authors use land cover classes as a starting point to assess ecosystem services (Ericksen et al. 2011; Koschke et al. 2012; Fang et al. 2015). Burkhard et al. (2009) propose "Landscapes' Capacities to Provide Ecosystem Services" as a concept for landcover-based assessments. Studies conducted in Europe mostly use the 44 land cover classes of the European CORINE project (Burkhard et al. 2009; Ericksen et al. 2011; Burkhard et al. 2012; Koschke et al. 2012; Burkhard et al. 2014; Fang et al. 2015).
For research in the global South,FAO (2003) provides a list of 99 land cover classes adaptable to various contexts.

Ecosystem service assessment methods are well established. However, there is less literature on agroecosystem services. One can argue that we could have directly used the ecosystem methods, but ecosystems differ fundamentally from agroecosystems. The main difference is their productivity objective and the politically or socially defined boundaries, expressed as collective or private properties on land. Consequently, food systems are a patchwork of agroecosystems in which, instead of natural units, we find land cover classes heavily influenced by human activities that must be made comparablefor different agroecosystems. As mentioned, we build on the method of ecosystem services proposed by Burkhard et al. (2009). However, their method does not propose a formula to calculatethe ASC of different land cover classes, nor doesit present aggregate index values for the agroecosystem (see section 3). For our case, it was fundamental to assessthe environmental performance of food systems by developing a method that could determine their capacity to provide agroecological services.

\subsection{Agroecosystem services and land cover classes}

An agroecosystem is an area of an ecosystem that has been transformed by human agricultural interventions into an agroecosystem (Altieri 1983; Hart 1985; Conway 1987; Altieri 1999; Gliessman 2007). More concretely, an agroecosystem is a spatially and functionally coherent unit of agricultural activity that includes living and non-living components and their interactions, (Dominati et al. 2014). Assessing the capacity of agroecosystems to provide agroecosystem services in the context of food systems is a challenge in practical terms, as agroecosystems are often made up of multiple farms, making it difficult to assess agroecosystem services across an entire agroecosystem. 
A key aspect inassessing ASC is to understand the relation between ecosystems, agroecosystems, and farming systems (or farms). The agroecosystem concept provides a framework for analysing food production systems in their entirety, including their complex sets of inputs and outputs and the interconnections between their component parts (Gliessman 2007). Conway (1987) argues that agroecosystems can be conceived within a classical hierarchy of systems: at the bottom of the hierarchy is the agroecosystem comprising the individual plant or animal, its immediate micro-environment, and the people who manage it. Articulated to this is a next component concerning the field and farm level, and the hierarchy continues upwards in this way, each agroecosystem forming a component of the agroecosystem at the next level (Conway 1987).

For the purpose of this study, we understand agroecosystems as areas of an ecosystem that have been transformed by human agricultural interventions resulting from different types of production systems that are shaped by the humans managing a farm. We therefore consider it adequate to use a concept of agroecosystems that includes production systems as a major cause of the transformation of ecosystems into agroecosystems. We adopt an agroecosystem framework to study food production systems because it enables us to assess farms not simply as units of biomass production, but as comprehensive entities that have the capacity to produce biomass as well as other, sometimes numerous, additional farm-based agroecosystem services. This means that we determine the farmbased agroecosystem services provided by specific sections of an agroecosystem, represented by farming units, which at a higher level constitute the wider landscapes. The basic unit of analysis, therefore, is the sections of agroecosystems managed by specific farms. We refer to these as "farm-based agroecosystems" (FBAs), and to the number and types of agroecosystem services they provide as "farm-based agroecosystem services" (FBA services). We use the land cover classes in the FBAs as the lowest empirical unit of analysis and assess the capacity of each land cover class in an FBA to provide FBA services.
Prominent features of FBAs are the different land cover classes, such as irrigated or rainfed cropland, roads, forest plantations, and rural settlements. FBAs are shaped by agricultural interventions, which include ploughing, planting, irrigation, application of agrochemicals, and harvesting (Gliessman 2007). The management decisions that define the type of agricultural interventions are influenced by the food systems to which the FBAs belong. An FBA that is part of an agro-industrial food system will probably use different machinery, seeds, and agrochemicals than an FBA that is part of a local food system. At the same time, the land cover of an FBA also reflects its underlying geological, geomorphological, climatic, and related biological macro conditions. This is in line with Di Gregorio's (Di Gregorio 2016, p. 1) description of land cover as the "a synthesis of the many processes taking place on the land". According to him, land cover reflects the occupation and the transformation of land by various natural and anthropogenic systems and, to some extent, how these systems affect the land (Di Gregorio 2016). We therefore consider land cover asuitable indicator to help measure the effects of human interventions on an FBA. More concretely, we propose transferring the methodology that Burkhard et al (2012) developed for assessing ecosystem services to the concept of agroecosystem services. In other words, we propose considering agroecosystem services as the capacity of specific networks of land cover classes (of a specific FBA) to provide a specific bundle of agroecosystem goods and services.

Each land cover class in an FBA has the potential to provide agroecosystem services. Agroecosystem services are goods and services that the FBA can provide and which contribute to human wellbeing (Zhang et al. 2007; Lescourret et al. 2015). Agroecosystem services can be provisioning services, regulating services, supporting services, or cultural services (Kyösti \& Olli 2013; Wiggering et al. 2016). Burkhard et al. (2012), propose two ways of defining the capacity of land cover classes to provide ecosystem services: as i) the capacity of a land cover class to provide the set of services actually used (directly or indirectly, by a group of people); and ii) the capacity of an area of land with a specific 
land cover to provide the hypothetical maximum supply of services that land cover class is capable of providing. Thus, we use the first notion of capacity and adapt it to the agroecosystem context.

In our approach, we consider the capacity of a land cover classto provide FBA services for the biophysical characteristics of the land cover class as well as its function regarding anthropogenic aspects such as management decisions or know-how (see left side of Fig. 1). For example, a certain land cover class may have the potential to provide timber. However, if nobody extracts timber, this land cover classinstead of providing a direct FBA services to humans - provides regulating and maintenance services to the FBA or the Earth system by increasing the amount of biomass in the FBA or capturing carbon dioxide, respectively. Similarly, another land cover might contain medicinal plants, but if nobody knows how to use them, the land cover is not providing this FBA services.

Within the Earth system (green line in Fig. 1), various food systems coexist: for illustration purposes one typical global food system is depicted on the top left. Input supplies from the global market are transported to production units that we call FBAs. The products are then processed, packaged in the region, and retailed by global markets to finally reach the consumers. Food systems provide the social, economic, and political dimensions that influence the types of management decision that will be made in the FBA. The natural resource base or biophysical structures and processes of ecosystems provide

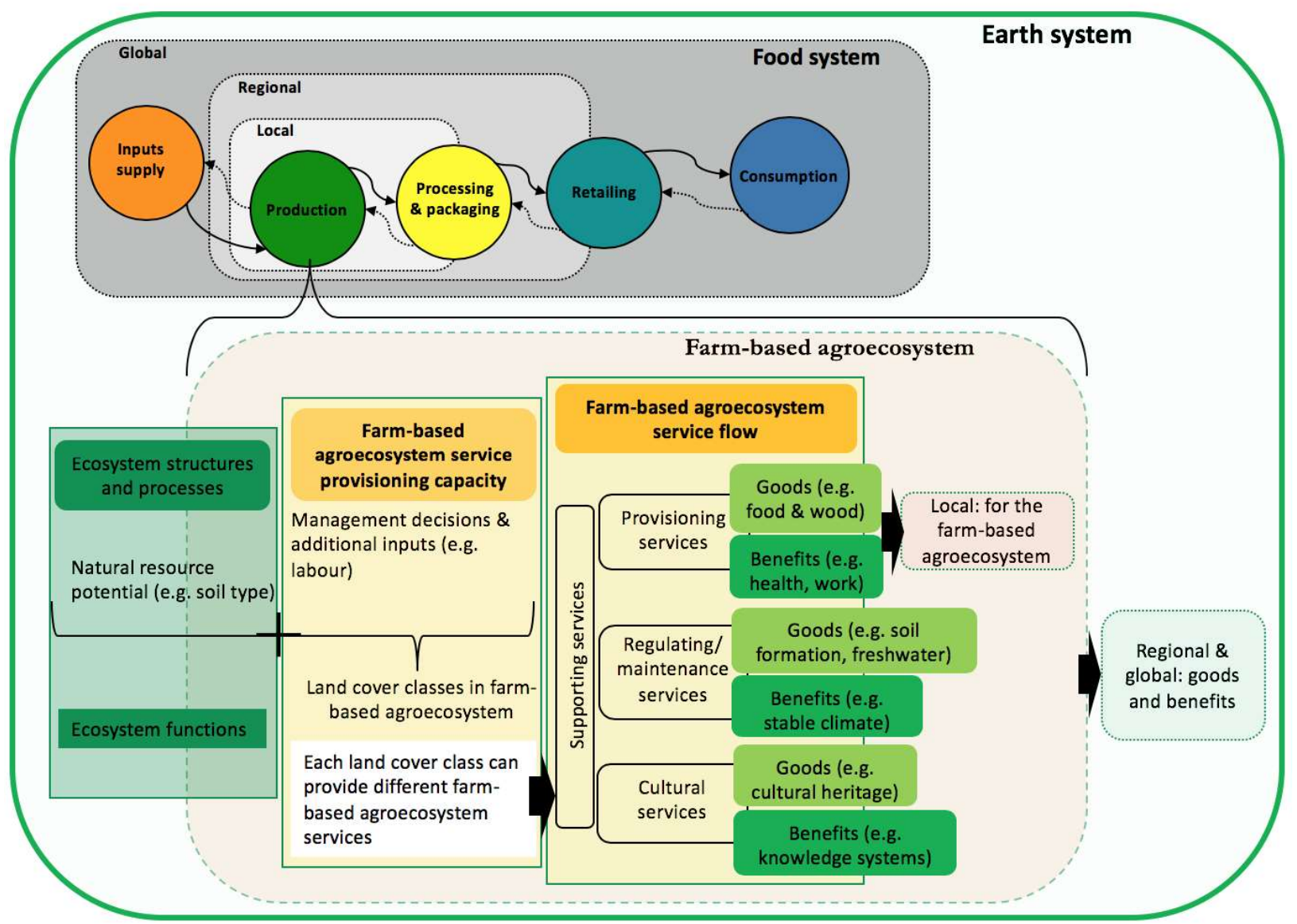

Figure 1: Conceptual model of afarm-based agroecosystem within a food system. The figure describes the relation between Earth system,food system, ecosystem, farm-based agroecosystem, land cover classes and their capacity to provide farm-based agroecosystem services. (Own illustration based on Burkhard et al. (2012), Common International Classification of Ecosystem Services (CICES) by Haines-Young \& Potschin (2013) and (de Groot et al. 2010). 
the physical space where the FBA exists (see Fig. 2). An FBA is a combination of the natural resource potential plus the human inputs and decisions (Altieri 1983) that create the land cover classes which can/cannot provide agroecosystem services. Ecosystems provide an array of ecosystem services (Millennium Ecosystem Assessment 2005; Cardinale et al. 2012; Haines-Young \& Potschin 2013); FBAs can provide some of them (see Tab. 1). Agroecosystem services can be divided into four types of service: provisioning, regulating/maintenance, and cultural services on the one hand (Kyösti \& Olli 2013; Wiggering et al. 2016), and supporting services on the other (Ma et al. 2015). Supporting services differ from the first three types of service in that they have a transversal role, influencing the capacity of FBAs to provide the other three services. Each type of agroecosystem service can provide goods (tangible products) and benefits (intangible products). The goods and benefits can stay in the FBA and build it up (benefits such as foliage that fallsonto soil and regenerates it) or be transported out of the FBA to other landscapes in the region or the Earth system (such as carbon dioxide capture, which benefits the Earth system).

Ecosystems are similar to FBAs, but there are also fundamental differences. The services of both types of system can be categorized as provisioning, regulating/maintenance, cultural, and supporting. The main difference is that an ecosystem is an area with ill-defined boundaries in which a dynamic complex of biotic and abiotic components freely interact. An FBA is a well-defined area with a dynamic complex of biotic and abiotic components, but with their interactions conditioned by human interventions to obtain outputs (as agroecosystem services) such as food, feed, or fibre, which are generally preferred by farmers and markets. Human interventions in FBAs can be characterized by the use of external inputs (fossil energy, fertilizer, pesticide, etc.) that could be replaced by inputs from ecosystem services (e.g. nutrients from soil mineralization), as described in the analytical framework proposed by Therond et al. (2017).

\section{The Agroecosystem Service Capacity approach}

The Agroecosystem Service Capacity (ASC) approach aims at assessing the capacity of the land cover classes of an FBA to provide one or several of a maximum of 20 different agroecosystem services. The approach provides results for each land cover class and is the basis for calculating an aggregate index for the whole FBA. The results allow us to compare different FBAs, and, within these, the capacities of the land cover classes.

A tool suitable for its local context was developed during two-and-a-half years of research on 18 farms belonging to three typical food systems in Latin America and three in Africa (details of the fieldwork are contained in section 4). In section4, we describe how we applied the ASC, and provide the results from one farm belonging to one food system each in Kenya and in Bolivia.

To develop the ASC approach we followed four steps: i) Land cover classification: We defined an approach for land cover classification in FBAs (section 3.1). ii) Agroecosystem services: We defined which of the commonly used ecosystem services in the scientific literature are relevant for FBAs directly related to and shaped by food systems (section 3.2). iii) Indicators and rating scale: We identified the indicators needed to assess each FBA services and created a rating scale for each indicator adapted to the foodsystemcontextandthe dataavailable(section 3.3). iv) Matrix: We developed an Agroecosystem Service Matrix that serves for aggregating the data collected and calculating an ASC for each land cover class and an ASCIndex for the whole FBA (section 3.4).

\subsection{The method and tools for land cover classification in food systems related agroecosystems}

Land cover classes are the basic unit of analysis to assess an FBA (see section 2.2). Therefore, a fundamental step of the ASC approach is to classify 
the land cover of the FBA. Land cover classification comprises two main steps:

i) Fieldwork to collect data on the different land cover classes. The data should also provide information on the 20 agroecosystem services described in section 3.2 and enough information to rate the capacity of each land cover to provide the 20 agroecosystem services according to the rating scale in section 3.3. ii) Carry out a land cover classification of the studied FBA. A useful list for classifying the land cover of FBAs is provided by FAO (2003).

It offers 99 globally applicable land cover classes, subdivided into seven categories. The seven categories (with an example of each of land cover class in parentheses) can be summarized as: i) cultivated terrestrial areas and managed lands (e.g. irrigated herbaceous crop); ii) natural and semi-natural terrestrial vegetation (e.g. closed trees with shrubs); iii) cultivated aquatic or regularly flooded areas (e.g. rice); iv) artificial surfaces and associated areas (e.g. industrial area); v) bare areas (e.g. bare soil); vi) artificial waterbodies (e.g. artificial lakes or reservoirs); and vii) inland waterbodies (e.g. river).

The list contains most of the land cover classes found in the FBAswe studied. For cases where a land cover class is noton the FAO list (2003), Di Gregorio (2016) provides a comprehensive land cover classification method that can be used complementarily. To create the land cover maps for each FBA we used Google Earth and QGIS software.

\subsection{The 20 agroecosystem services}

As mentioned in section 2.2, an FBA is an ecosystem that is managed for agricultural purposes. In order to assess the capacity of the land coverclass to provide agroecosystem services, it is important first to define which of the ecosystem services used in ecosystem literature are relevant in agriculture as agroecosystem services. To build on existing literature, we first listed in atable the ecosystem services that were initially proposed by the Millennium Ecosystem Assessment (2005). Second, we added to this table all ecosystem services listed in the Common International Classification of Ecosystem Services (CICES) (HainesYoung \& Potschin 2013). In the same table, we listed all ecosystem services proposed by Burkhard et al. (2009); Burkhard et al. (2012); Koschke et al. (2012); Burkhard et al. (2014); and Burkhard et al. (2014), because they all use land cover classes as a basic unit to assess an ecosystem's capacity to provide ecosystem services. Additionally, using the search term "agroecosystem services" in Scopus and Google Scholar, we identified two further author groups, Garbach et al. (2014); Ma et al. (2015), who also propose lists of ecosystem services related to agriculture. We included all these lists in one table. This resulted in a list of ecosystem services that could be related to agroecosystem services. The list had eight rows, each row representing a different literature source and containing the ecosystem services proposed by the author that can relate to agroecosystem services.

From this table, we selected the ecosystem services relevant for the FBA services assessment according to two criteria: i) The production space of the food systems (e.g. farms) must show land use classes that can be directly related to the list of specific ecosystem services; and ii) the ecosystem service must have been mentioned in at least two of the literature sources of the above list. We included the ecosystem services that were most commonly used in the literature and that coherently existed in the field research sites (excluding fisheries or aquaculture, as they did not exist at the research sites).

We compiled 20 agroecosystem services that are adapted to any type of FBA. In Tab.1, they are organized and classified according to the CICES used by Haines-Young and Potschin (2013). There are nine provisioning services, eight regulating/maintenance services, two cultural services, and one supporting service.

Provisioning services are goods and services that provide nutritional, material, and energetic outputs (Haines-Young \& Potschin 2013). Regulation and maintenance services cover mediation of flows of solids, liquids, and gases that affect ways living 
Table 1: Agroecosystem services and their corresponding classes, definitions, and land cover classes.

\begin{tabular}{|c|c|c|}
\hline CLASS & DEFINITION & POTENTIAL SERVICE-PROVIDING UNITS \\
\hline Agroecosystem service & Services that the land cover class can provide & Land cover classes that can provide agroecosystem services \\
\hline \multicolumn{3}{|c|}{$\begin{array}{l}\text { PROVISIONING SERVICES } \\
\end{array}$} \\
\hline Food crops & Provisioning of edible plants & Cropland, gardens, fruit plantations ${ }^{1,2}$ \\
\hline $\begin{array}{l}\text { Wild foods \& other } \\
\text { resources }\end{array}$ & Fruits, mushrooms, plants, wild animals, fish ${ }^{1,2}$ & Forests, grasslands, agricultural fields, waterbodies, water courses ${ }^{1,2}$ \\
\hline Livestock & $\begin{array}{l}\text { Domestic animals for nutrition and by-products (e.g. dairy, eggs) } \\
1,2\end{array}$ & Pastures, farms, stables, grassland, agroforestry ${ }^{1,2}$ \\
\hline Fodder & Nutritional substance for domestic animals ${ }^{1,2}$ & Grasslands, pastures, agroforestry, marshlands ${ }^{1,2}$ \\
\hline Biochemical/medicine & $\begin{array}{l}\text { Natural product usable as biochemical, medicine, and/or } \\
\text { cosmetics }^{2}\end{array}$ & Forests and gardens ${ }^{2}$ \\
\hline Seeds & Seeds to support natural and semi-natural land cover classes ${ }^{3}$ & Agricultural fields and natural vegetation \\
\hline Timber & Wood usable for human purposes (e.g. construction) ${ }^{2}$ & Forests, silvicultural areas, agroforestry ${ }^{2}$ \\
\hline Wood fuel & Wood suitable for energy conversion and/or heat production ${ }^{2}$ & Forests, hedgerows, agroforestry ${ }^{2}$ \\
\hline Freshwater & Water available for drinking, irrigation or industrial use ${ }^{2}$ & Rainwater harvesting system \\
\hline \multicolumn{3}{|c|}{ REGULATING AND MAINTENANCE SERVICES } \\
\hline Local climate regulation & Changes in local climate (wind, temperature, radiation) $^{2}$ & Forests, wetlands, lakes, (urban) green areas, agroforestry, hedges ${ }^{2}$ \\
\hline Global climate regulation & Storage of potential greenhouse gases in land cover class ${ }^{2}$ & Soils and forest (standing biomass) ${ }^{2}$ \\
\hline Erosion regulation & $\begin{array}{l}\text { Soil retention and the ability to prevent and mitigate soil } \\
\text { erosion }\end{array}$ & Natural, semi-natural and cultivated land covers ${ }^{2}$ \\
\hline Nutrient regulation & Ability to recycle nutrients (e.g. $\mathrm{N}, \mathrm{P}, \mathrm{K}$, etc.) ${ }^{2}$ & Natural, semi-natural and cultivated land covers ${ }^{2}$ \\
\hline Water purification & Ability to purify water (e.g. sediments, pollutants, nutrient) ${ }^{2}$ & Waterbodies, riparian strips, filtrating soils, forest ${ }^{2}$ \\
\hline Water regulation & Water cycle feature maintenance (e.g. water storage) ${ }^{2}$ & Waterbodies, riparian strips, filtrating soils, forest ${ }^{2}$ \\
\hline Pollination & Bees, birds, bats, moths, flies, wind, non-flying animals ${ }^{2}$ & Gardens, fruit plantations, forest, wetlands, agricultural areas ${ }^{2}$ \\
\hline Biological control & Ability to control pests and diseases due to genetic variation ${ }^{2}$ & Forests, wetlands, waterbodies, gardens, agricultural areas ${ }^{2}$ \\
\hline \multicolumn{3}{|c|}{ CULTURAL SERVICES } \\
\hline Knowledge systems & Capacity to enhance the creation and sharing of new knowledge & All land cover classes \\
\hline Heritage \& diversity & Ability to maintain historical landscapes ${ }^{2}$ & All land cover classes ${ }^{2}$ \\
\hline \multicolumn{3}{|c|}{ SUPPORTING SERVICES } \\
\hline Biotic heterogeneity & $\begin{array}{l}\text { Diversity of natural and semi-natural vegetation, } \\
\text { agrobiodiversity }^{1}\end{array}$ & Natural, semi-natural, and cultivated land covers ${ }^{2}$ \\
\hline
\end{tabular}

\footnotetext{
${ }^{1}$ Burkhard et al. (2009)
}

${ }^{2}$ Burkhard et al.(2014)

organisms can regulate the physicochemical and biological environment (Haines-Young \& Potschin 2013), which indirectly also affects humans. Regulating services are challenging to measure, because humans benefit indirectly and they comprise several interconnected ecosystem processes that depend on different ecosystem properties (Villamagna et al. 2013). Cultural services are the intangible services that affect the physical and mental states of people (Haines-Young \& Potschin 2013). Cultural services are also challenging to assess as they are subjective and non-material (Burkhard et al. 2014).

In our understanding, an FBA can be expressed by the land cover classes it encompasses (structural diversity). These land cover classes contain a variable amount and diversity of plants and animals (biological diversity). We regard biodiversity as a precondition for land cover classes to be able to provide certain agroecosystem services (Altieri 1999). Biodiversity enhances a variety of services beyond production of food, including recycling of nutrients, regulation of microclimate and local hydrological processes, suppression of undesirable organisms, and detoxification of noxious chemicals (Altieri 1999). Agrobiodiversity also makes the FBA more resilient (Lin 2011; Jacobi et al. 2015). For the above reasons, we included the supporting services as mentioned in the Millennium Ecosystem Assessment (2005) considering the indicator of biotic heterogeneity (see ASC Toolbox in Annex). Structural heterogeneity is indirectly integrated in the ASC index, because the number of different land cover classes is a fundamental component of the ASC Index (see formulas in Tab.2, Agroecosystem Service Matrix.) 


\subsection{The rating scale and indicatorsof ASC}

The rating scale and indicators are central elements of the ASC approach. We developed a rating scale adapted to the indicators of each FBA service that can be assessed with primary data collected from farmers.

To create the rating scale, we followed the approach of Burkhard et al. (2009) by taking the maximum values identified in our sample as the reference values representing rating 5 (=very high capacity to provide the flow of current FBA services in one normal year). Rating 0 (=no capacity) was given when the land cover provided no service at all. The steps in between were defined by halving the maximum value (to define the medium high capacity $=3$ ) and then putting equal steps between the remaining values (1=low capacity, $2=$ relevant capacity, and 4=high capacity) (see ASC Toolbox in Annex for details on each FBAS and its rating scale).

To assess the capacity of each land coverclass to provide ecosystem services, Burkhard et al. (2009); (2014) presents a list of potential indicators. From this list we selected the indicators that best matched the food system context in which we aimed to create easy-to-use indicators that can, eventually, also feasibly be applied by non-scientist actors (see ASC Toolbox in Annex for details). For example, we did not use the indicators that required soil or water samplingas suggested for the ecosystem service "water purification", which would mean measuring total dissolved solids in $\mathrm{mg} /$ litre of water or sediment load in grams/litre of water. Quantifying such indicators is complex, and in practical terms it would be almost impossible to isolate the effects caused by factors within or outside a specific food system. In cases like water purification services we decided to use activity-based proxy indicators: instead of quantifying the capacity to purify water by sampling water, we assessed the number of activities that are carried out in the management of a specific land cover class that can enhance or hinder the capacity of the land cover class to provide e.g. clean water (see activity-based proxy indicators in the next paragraphs). Another important aspect concerns creating indicators that are adapted to the diverse types of sources from which we can obtain data on the different kinds of land cover classes. For example, for a production land cover class, stakeholders know the annual yield of food produced in $\mathrm{tn} / \mathrm{ha}$; whereas in terms of soil quality they have no quantitative data, but they see and perceive soil degradation. In order to be able to use both sources of knowledge, we developed indicators based on numeric and on qualitative information. We identified four main groups of sources covering different types of indicators:

1 Quantitative indicators: Refers to quantities of certain goods and services that the land cover class can provide, for example tonnes of food produced per hectare (Burkhard et al. 2014). This type of indicator is mostly used for provisioning FBA services because farmers can, in most of the cases, provide the data (see ASC Toolbox Annex).To set the range (highest and lowest) of the rating scale for these quantitative indicators, the highest value of the scale ( $5=$ high capacity), was assigned to the highest quantitative value that we registered in the land cover classes in concrete empirical cases; the lowest value $(0=$ no capacity) was given to the land cover classes that did not provide any specific service.

2 Qualitative indicators: Refers to qualitative information based on the perceptions of FBA managerson land cover class capacity to provide FBA services that are difficult to quantify. For example, we used the perceptions of FBA managers to describe the capacity of a land cover class to provide FBA services, e.g. related to local climate regulation or nutrient regulation among others (see ASC Toolbox Annex for details).

3 Activity-based proxy indicators: Are agricultural or management activities that can promote or hinder the capacity of land cover classes to provide specific FBA services. In the ASC Toolbox in Annex 1, we provide a list of activity-based proxy indicators that we found in the literature under "good agricultural practices"(FAO Grieg-Gran \& Gemmill-Herren 2012; 2013). This type of indicator is mostly used for regulating services that are complex and difficult to 
quantify. For example, the amount of water a certain land cover class can store is difficult to quantify; however, there are studies that provide lists of agricultural activities that promote or hinder water regulation, such as mulching, water harvesting, agroforestry, breeding, and selecting crop species and varieties adapted to the local climate (FAO 2013). The activity-based proxy lists (see ASC Toolbox Annex) were used for assessing land cover class capacity to provide specific FBA services by counting the number of "good agriculture activities" that are implemented in each land cover class. For example, if in a land cover class three of the afore mentioned good agricultural activities for water quality regulation are applied, the land cover class is assigned " 3 " for its capacity to provide water regulation as an FBA services.

The maximum value of the scale ( $5=$ very high capacity) for the activity-based indicators is assigned to land cover classes where all the activities listed in ASC Toolbox Annex for the specific FBA services are applied. The lowest value ( $0=$ no capacity) is given if none of the mentioned activities are implemented in land cover class.

4 Vegetation cover proxies. For natural and seminatural land cover classes the capacity to provide specific FBA services is assessed using vegetation cover as a proxy.

In this type of scale, the maximum value of 5 (=high capacity) is assigned when the vegetation cover consists of multi-layered trees (i.e. similar to natural vegetation of the area); 1 (=low capacity) is assigned when the vegetation in the land cover class is open herbaceous vegetation; and 0 (=no capacity) is assigned when a land cover class consists of bare soil or is an industrial area (for details see ASC Toolbox in Annex). This indicator is based on the idea that to create sustainable FBAs, we need to create natural ecosystem-like characteristics in FBAs (Gliessman 2007).

The rating needs a well-defined spatial and temporal scale. The spatial scale is given by the boundaries of the FBA. Within FBA boundaries (i.e. farm boundaries), the area of each land cover class is known. For the temporal scale, we took the maximal flow of FBA services in one normal agricultural year in the study area. We refer to a normal agricultural year when average weather and market conditions allowed for routine farm management. Therefore, the ASC results provide an assessment for the capacity of each land cover class to provide specific FBA services in one normal year.

\subsection{The Agroecosystem Service Matrix:} Aggregating food system related land cover class capacities to provide farm-based agroecosystem services

In the previous sections we described the method for land cover classification and the definition of individual related FBA services, both of which are the building blocks of what we call the Agroecosystem Service Matrix (ASM). The ASM is a central component of the Agroecosystem Service Capacity (ASC) approach. The ASC approach integrates the information on land cover class capacities to provide each of the 20 FBA services (see first row in a Tab. 2). It also allows us to calculate the Agroecosystem Service Capacity (ASC) of each land cover class and then express it in the aggregate ASC Index describingthe whole FBA.

The ASM is inspired by what Burkhard et al. (2009) called the "Ecosystem Service Matrix". The rows of the ASM (seeTab. 2), are the land cover classes of the FBA; the number of land cover classes depends on the FBA studied. The columns of the ASM are the 20 FBA services (defined in section 3.2). In the intersection, the results of the rating scale are inserted as described in section

To compare the capacity of each land cover class to provide FBA services, we developed the Agroecosystem Service Capacity (ASC) equation (see details in Tab. 2). The equation permits us to assess the capacity of land cover classes (related to specific food systems) to provide FBA services and provides results between $0=$ no capacity and $5=$ high capacity: 
Table 2: Example of an empty Agroecosystem Service Matrix (ASM): The number of land cover classes (rows) depends on the amount and type of land cover classes present in the FBA. In the columns are the 20 FBA services that we propose as a starting point and can be adapted according to the local context. The second row of the matrix provides the equations for the calculations in the corresponding column. The last column on the left is the equation to calculate Agroecosystem Service Capacity (ASC) per land cover class. The ASC Index is the sum of all ASCs depicted in the yellow box.

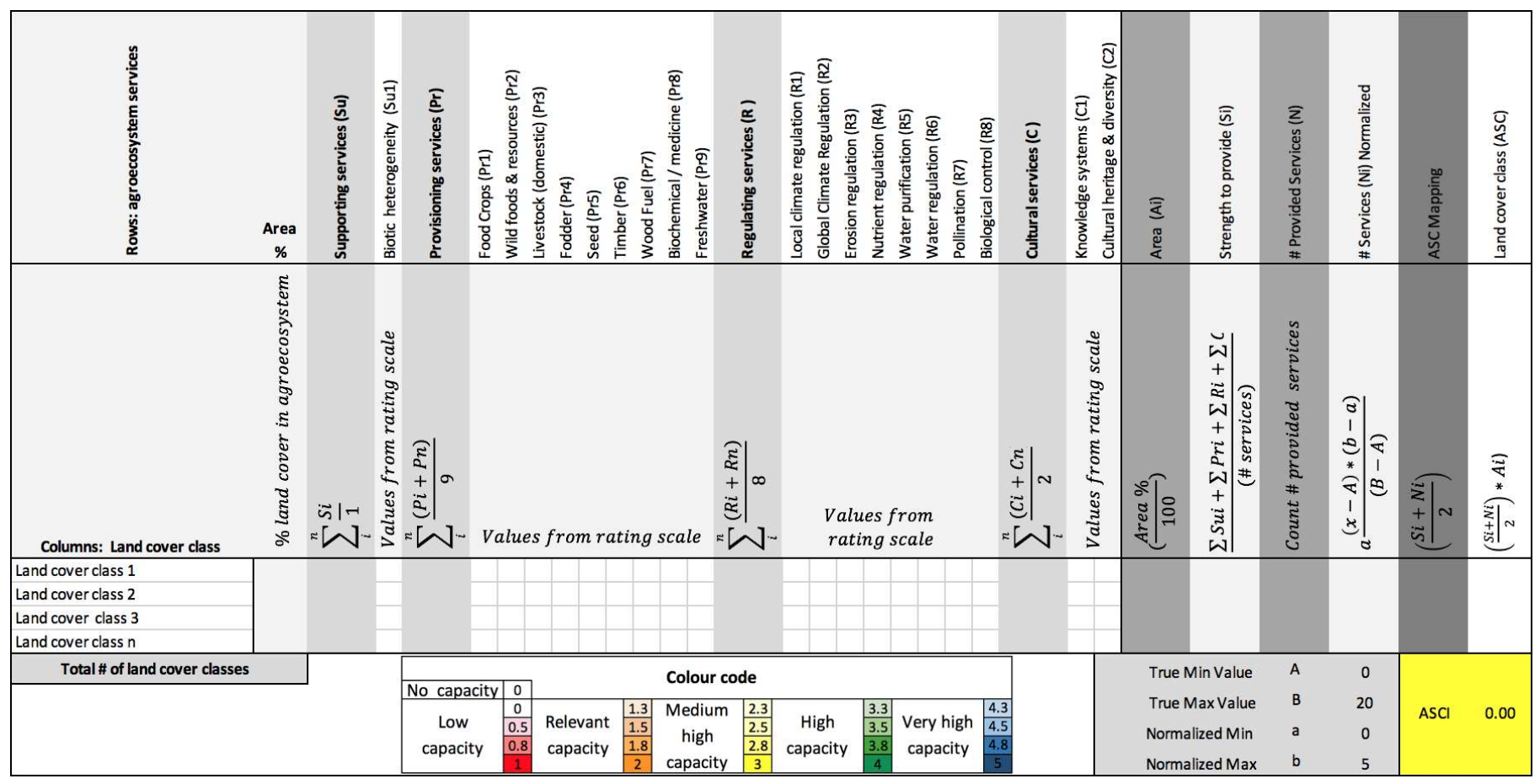

Equation 1: Agroecosystems service capacity

$$
A S C=\left(\frac{S i+N i}{2}\right) * A i
$$

Where:

$A i=$ Percentage of area occupied by the land cover class within the FBA

$\mathrm{Ni}=$ Number of FBA services the land cover class can provide

$S i=$ Strength of the land cover class in providing each of the FBA services

The area $(A i)$ occupied by the land cover class within the agroecosystem in per cent of the farmarea gives an indication of the importance of the land cover class within the agroecosystem. For example, in the ASM in Tab. 3, the land cover class Forest Plantation Angiosperm Native has a strength (Si) of 1.55 and provides 10 out of 20 FBA services ( $\mathrm{Ni}=2.50$ ). However, its ASC of 0.04 is very low because the area $(A i)$ this land cover class occupies within the FBA is only very small $(1.79 \%)$.

The number of FBA services ( $\mathrm{Ni}$ ) that the land cover class can provide is calculated by counting the number of times the land cover has a value greater than zero for the specific service in the ASM (not adding the values). Next, this number is normalized on a scale from zero to five (see Tab. 2). Ni provides insights on the multifunctionality of the land cover. In our view, multifunctionality and diversity are essential for sustainability. For example, in an FBA where only one crop is grown (soybean in Bolivia) it is common to see that one land cover class occupies a vast surface $(A i)$ of the FBA and has a lot of strength (Si) but an overall low ASC, because it provides only one or two FBA services out of 20 that could be provided. 
The strength $(\mathrm{Si})$ of the land cover classes in providing specific FBA services is represented by the value in each cell in the ASM. The Si value is obtained from the rating (explained in section 3.3), from zero to five, of the land cover class capacity to provide each one of the 20 FBA services. Si is the sum of ratings that each land cover class of the FBA has, divided by the number of FBA services. For example, in the ASM in Tab. 3 for the first land cover, irrigated herbaceous crop, the land cover class occupies a large area of the FBA (83\%) and provides 8 out of the 20 FBA services (equal to $\mathrm{Ni}=2$ ), but it has a low strength of 0.78 (on a scale from 0 to 5 ), so the ASC of the land cover class is $1.16=$ low capacity. It is important to highlight that we consider Sito relate not to land cover classes alone, but also to the FBA services and their characteristics. We use the Si of land cover classes as a proxy to assess the capacity of FBAs to provide FBA services.

With this component of ASC we address the issue of imbalance between the number of FBA services in each section (e.g. nine provisioning, one supporting). This we do by dividing the total strength of the land cover class by the total number of FBA services (20), in order to give each FBA service the same importance in the ASC Index (see formulas in Tab. 2).

The ASC values of the different land cover classes can be mapped by assigning a colour code to each land cover class depicting the land cover's capacity to provide FBA services. This ASC Map is calculated by multiplying the strength (Si) by the number of services (Ni), without including the area $(A i)$ in the multiplication because the area the land cover class occupies within the FBA will be illustrated in the map. The colour is assigned to the land cover class according to the ASC Map value of each land cover class. The colour code usedin the example in section 4 is $0=$ no capacity: white; $1=$ low capacity: grey; $2=$ relevant capacity:red; 3=medium high capacity:yellow; 4=high capacity:blue; and 5=very high capacity:green.

The ASC values provide information on each land cover class of the FBA (see last column in Tab. 3). In order to compare one FBAto others the ASC values are added up to obtain the ASC Index.
Equation 2: Agroecosystem Service Capacity Index

$$
A S C I=\sum_{i}^{n} A S C
$$

Where:

$A S C=$ the values of $A S C$ of each land cover class in the FBA (last column in ASM).

The ASC Index provides an aggregated estimate of the capacity of the entire FBA to provide FBA services. The ASC Index can be used to compare different FBAs and to assess specific indicators of food system sustainability.

The ASC Toolbox in the Annexis the central part of this approach: it provides the main tools for ASC assessment. It is arranged according to the four main types of FBA services: provisioning, regulating/ maintenance, cultural, and supporting services. For each FBA services the Toolbox provides a definition of the land cover classes that provide a specific FBA services, a detailed description of the indicators used to assess the FBA services, proposed guiding questions to collect data on land cover class capacity to provide the FBA services, and the scale for rating the capacity of each land cover class to provide the 20 FBA services. The ASC Toolboxis a starting point for ASC assessment, and can be adapted to local contexts by adding other FBA services or removing the services that are not relevant in the given context.

\section{Empirical application of the Agroeco- system Service Capacity approach in food systems}

The method was created, tested, and applied in 18 FBAs: nine in Bolivia and nine in Kenya.In this section, we illustrate the applicability of the Agroecosystem Service Capacity (ASC) approach by presenting the method and results of one application in Kenya, at an agro-industrial horticulture farm in Nyericounty $(\mathrm{Ag}-1 \mathrm{~K})$, and one in Bolivia, at an agroecological horticulture farm in Samaipata (Ae-1B) (see Tab.3). 
Table 3: Main characteristics of two farm-based agroecosystems used to demonstrate the applicability of the ASC approach.

\begin{tabular}{|c|c|c|}
\hline $\begin{array}{l}\text { Farm-based } \\
\text { Agroecosystem }\end{array}$ & Agroecological,Bolivia (Ae-1B) & Agro-industrial, Kenya (Ag-1K) \\
\hline Type & $\begin{array}{l}\text { Local commercial agroecological } \\
\text { horticulture; salads, herbs, } \\
\text { cabbages, and fruits; farm size } 4 \text { ha. }\end{array}$ & $\begin{array}{l}\text { Export-oriented intensive commercial } \\
\text { horticulture; broccoli, French beans, } \\
\text { sugar snaps, runner beans, pakchoy; } \\
\text { farm size 48ha. }\end{array}$ \\
\hline $\begin{array}{l}\text { Food } \\
\text { production }\end{array}$ & $\begin{array}{l}\text { Land preparation is done with } \\
\text { tractors; planting, cultivation and } \\
\text { harvesting are done manually. }\end{array}$ & $\begin{array}{l}\text { Land preparation, planting, and } \\
\text { cultivation are done with machinery; } \\
\text { harvesting is done manually. }\end{array}$ \\
\hline Agrochemicals & No reported use of agrochemicals & $\begin{array}{l}\text { Full dependence on agrochemicals for } \\
\text { production }\end{array}$ \\
\hline Accreditations & No & $\begin{array}{l}\text { Global Gap, Field to Fork, Albatage (for } \\
\text { herbs) }\end{array}$ \\
\hline Retail/exchange & $\begin{array}{l}\text { Some produce is sold locally; most } \\
\text { is sent to Santa Cruz }(120 \mathrm{~km} \\
\text { away). }\end{array}$ & $\begin{array}{l}\text { Cold chain is required for retail, most } \\
\text { products are exported to Europe and UK } \\
\text { by air. }\end{array}$ \\
\hline Consumption & $\begin{array}{l}\text { Consumers buy the product } \\
\text { because they know the farmers } \\
\text { (either in person or by reputation); } \\
\text { a small portion is consumed by } \\
\text { farmers. }\end{array}$ & $\begin{array}{l}\text { No link exists between producers and } \\
\text { consumers, products are consumed at } \\
\text { national and global level. }\end{array}$ \\
\hline
\end{tabular}

During fieldwork, we used semi-structured interviews, participatory FBA mapping, transect walks, visual soil assessment, and vegetation and soil sampling tools. The fieldwork data had to provide information on the capacity of each land cover class to provide the 20 FBA services. The list of 20 FBA services shown in Tab. 1 was used in all 18 case studies.

\subsection{The Agroecosystem Service Matrix}

Based on the fieldwork, we identified, described, and mapped land cover classes for agro-industrial horticulture in Kenya (Tab.4) and agroecological horticulture in Bolivia (Tab. 5). The land cover classifications and descriptions were the main input for rating land cover classes in terms of their capacity to produce each of the 20 FBA services using the rating scale described in section 3.3. The Agroecosystem Service Matrices (ASMs) in Tab.4 and Tab. 5 show the results of the rating, which were inserted as explained in section 3.4.
The agro-industrial horticulture FBA (see ASM in Tab.4) has an ASC Index of 1.31, which means it has a low capacity to provide FBA services. The land cover class "Irrigated herbaceous crop" has the highest ASC, which makes sense, asthis FBA is a horticulture farm. The FBA also includes three land cover classes representing different types of "Forest plantations", which altogether cover $13 \%$ of the total area of the FBA. This is more than the $10 \%$ required by the Kenyan Agriculture Farm Forestry Rules (2009). Surprisingly, however, the ASCs of the "Forest plantation" land cover classes are low: All have ASC values below 0.1 (see Tab.4). This is because they occupy very small areas $(\mathrm{Ai})(<1 \%)$ within the $\mathrm{FBA}$, strongly affecting the overall capacity of the land cover to provide FBA services. The agroecological horticulture FBA (see ASM in Tab. 5) has an ASC Index of 2.68, i.e. medium high capacity to provide FBA services. The land cover class Irrigated herbaceous crop (i.e. horticulture fields) has the highest ASC (1.24) and occupies $41 \%$ of the FBA. Overall, this agroecological horticulture FBA (Ae-1B) has double as much capacity to provide FBA services as the agro industrial horticulture FBA (Ag-1K). 
Table 4: ASM for an agro-industrial horticulture farm in Nyeri county, Kenya (Ag-1K). This FBA has eight identified land cover classes. For each land cover class, the capacity to provide $20 \mathrm{farm}$-based agroecosystem services was assessed on a scale from $0=$ no capacity (white) to $5=H i g h$ capacity (red) using the rating scale in the Agroecosystem Service Capacity (ASC) Toolbox (Annex). The penultimate column to the right depicts the values and colours used for each land cover class in the ASCMap(Fig. 2). The last column displays the ASC values for each land cover class. The ASC Index is the sum of all ASCs in the FBA, shown in the yellow box on the bottom right.

\begin{tabular}{|c|c|c|c|c|c|c|c|c|c|c|c|c|c|c|c|c|c|c|c|c|c|c|c|c|c|c|}
\hline 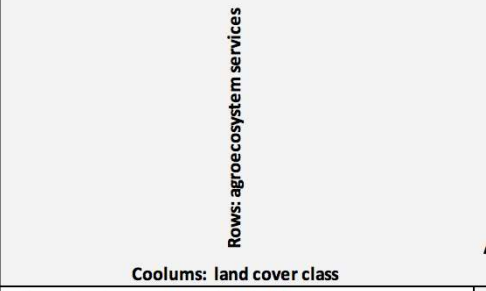 & $\begin{array}{c}\text { Area } \\
\%\end{array}$ & 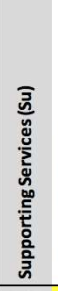 & 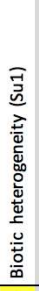 & 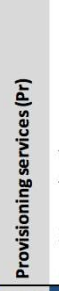 & 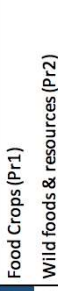 & 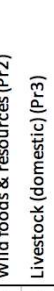 & 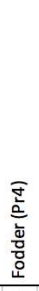 & 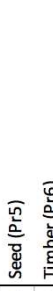 & 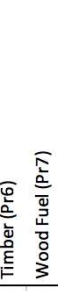 & 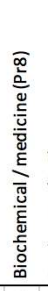 & 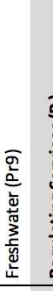 & 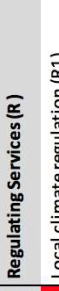 & 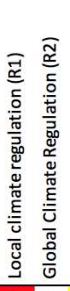 & 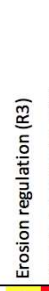 & 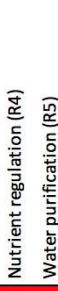 & 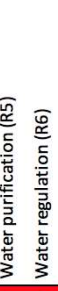 & 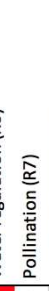 & 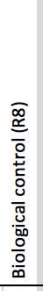 & 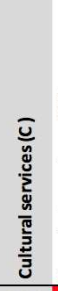 & 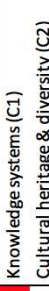 & 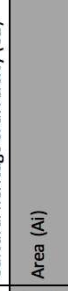 & 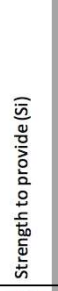 & 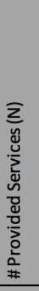 & 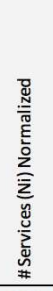 & 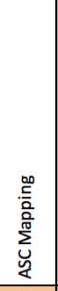 & 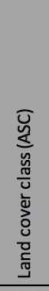 \\
\hline Irrigated herbaceous crop, horticulture & 83.50 & 3.00 & 3 & 0.56 & 5 & 00 & 0 & 0 & 00 & 0 & 00 & 0.81 & 0 & 3 & 1 & 11 & 0 & 0 & 0.50 & 10 & 0.83 & 0.78 & 8 & 2.00 & 1.4 & 1.16 \\
\hline Artificial lakes or reservoirs & 6.25 & 0.00 & 0 & 0.00 & 0 & 00 & 0 & 0 & 00 & 0 & 00 & 0.88 & 0 & 0 & 0 & 2 & 0 & 0 & 0.00 & 0 & 0.06 & 0.35 & 3 & 0.75 & 0.6 & 0.03 \\
\hline Bare soil/dirt roads & 4.17 & 0.00 & 0 & 0.00 & 0 & 0 & 0 & 0 & 0 & 0 & 00 & 0.00 & 0 & 0 & 0 & 0 & 0 & 0 & 0.00 & 00 & 0.04 & 0.00 & 0 & 0.00 & 0.00 & 0.00 \\
\hline Very open trees with closed to open shrubs, hedge & 2.81 & 2.00 & 2 & 0.11 & 0 & 00 & 0 & 1 & 00 & 0 & 03 & 3.38 & 2 & 4 & 4 & 4 & 4 & 5 & 0.00 & 00 & 0.03 & 1.50 & 10 & 2.50 & 2 & 0.06 \\
\hline Forest plantation- native (broad leaved) & 1.79 & 3.00 & 3 & 0.11 & 0 & 00 & 0 & 1 & 0 & 0 & 03 & 3.38 & 4 & 4 & 4 & 4 & 2 & 5 & 0.00 & 00 & 0.02 & 1.55 & 10 & 2.50 & 2.03 & 0.04 \\
\hline Forest plantation-exotic (broad leaved) & 0.85 & 3.00 & 3 & 0.11 & 0 & 0 & 0 & 1 & 0 & 0 & 03 & 3.13 & 2 & 4 & 4 & 4 & 1 & 5 & 0.00 & 0 & 0.01 & 1.45 & 9 & 2.25 & 1.9 & 0.02 \\
\hline Forest plantation-exotic (needle leaved) & 0.42 & 2.00 & 2 & 0.11 & 0 & 00 & 0 & 1 & 00 & 0 & 03 & 3.13 & 4 & 4 & 4 & 4 & 1 & 5 & 0.00 & 00 & 0.00 & 1.40 & 10 & 2.50 & 1.95 & 0.01 \\
\hline Industrial area-general & 0.21 & 0.00 & 0 & 0.00 & 0 & \begin{tabular}{l|l}
0 & 0 \\
\end{tabular} & 0 & 0 & 00 & 0 & $0 \quad 0$ & 0.00 & 0 & 0 & 0 & 0 & 0 & 0 & 0.50 & 0 & 0.00 & 0.05 & 1 & 0.25 & 0.15 & 0.00 \\
\hline \multirow{2}{*}{\multicolumn{4}{|c|}{ Total \# of land cover classes 8.00}} & \multicolumn{15}{|c|}{ Colour code } & & \multirow{2}{*}{\multicolumn{3}{|c|}{$\begin{array}{l}\text { True Min Value } \\
\text { True Max Value } \\
\text { Normalized Min } \\
\text { Normalized Max }\end{array}$}} & A & 0 & \multirow[b]{2}{*}{$\mathrm{ASCl}$} & \multirow[b]{2}{*}{1.31} \\
\hline & & & & & $\begin{array}{l}\text { apacity } \\
\text { ow } \\
\text { acity }\end{array}$ & \begin{tabular}{|l|l|} 
& 0 \\
0 \\
0.5 \\
0.8 \\
\end{tabular} & \multicolumn{2}{|c|}{$\begin{array}{l}\text { Relevant } \\
\text { capacity }\end{array}$} & \begin{tabular}{|l|}
1.3 \\
1.5 \\
1.8 \\
2 \\
\end{tabular} & \multicolumn{2}{|c|}{$\begin{array}{l}\text { Medium } \\
\text { high } \\
\text { capacity }\end{array}$} & \begin{tabular}{|c|}
2.3 \\
2.5 \\
2.8 \\
3 \\
\end{tabular} & \multicolumn{2}{|c|}{$\begin{array}{c}\text { High } \\
\text { capacity }\end{array}$} & \multicolumn{3}{|c|}{\begin{tabular}{|c|c|}
$\frac{3.3}{3.5}$ & Very high \\
3.8 & capacity \\
4 & cact
\end{tabular}} & \begin{tabular}{|l|}
4.3 \\
4.5 \\
4.8 \\
5
\end{tabular} & & & & & $\begin{array}{l}\text { B } \\
\mathrm{a} \\
\mathrm{b}\end{array}$ & $\begin{array}{c}20 \\
0 \\
5 \\
\end{array}$ & & \\
\hline
\end{tabular}

Table 5: ASM for an agroecological horticulture farm in Bolivia (Ae-1B). This FBA has twelve identified land cover classes. The assessment was done in the same way as for previous ASM in Tab.3.

\begin{tabular}{|c|c|c|c|c|c|c|c|c|c|c|c|c|c|c|c|c|c|c|c|c|c|c|c|c|c|c|c|c|c|c|c|}
\hline Agroecological Ae-1 & $\frac{\text { Area }}{\underline{\%}}$ & 氙 & $\overline{\vec{\exists}}$ & ఏ & $\stackrel{\bar{a}}{\underline{5}}$ & 章 & $\overline{\underline{m}}$ & 音 & 気 & $\begin{array}{l}\text { 哀 } \\
\underline{\underline{a}}\end{array}$ & 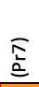 & $\begin{array}{l}\overline{\underline{\alpha}} \\
\underline{\underline{a}}\end{array}$ & 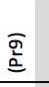 & $\underline{\underline{\Xi}}$ & $\widehat{\underline{\underline{\Xi}}}$ & $\widehat{\cong}$ & $\underline{\underline{m}}$ & 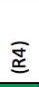 & 㐱 & 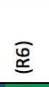 & $\widehat{\mathbb{\varrho}}$ & $\underset{\infty}{\mathscr{\infty}}$ & $\underline{\underline{\Xi}}$ & $\underline{\underline{J}}$ & $\underline{\underline{\tilde{g}}}$ & $\overline{\underline{s}}$ & 흐 & $\Sigma$ & $\frac{\grave{o}}{\grave{z}}$ & $\sum_{\substack{0\\
}}^{0}$ & 这 \\
\hline Rainfed ornamental-sparce trees & 8.83 & 4.00 & 4 & 0.42 & 0 & 0 & 0 & 0 & 2 & 1 & 2 & 0 & 0 & 3.50 & 1 & 1 & 4 & 4 & 5 & 4 & 4 & 5 & 3.00 & 4 & 2 & 0.09 & 2.15 & 14 & 3.50 & 2.83 & 0.25 \\
\hline Rainfed shrub crop-fruit trees (hedges) & 4.81 & 3.00 & 3 & 0.58 & 2 & 0 & 0 & 1 & 2 & 0 & 2 & 0 & 0 & 3.25 & 1 & 1 & 4 & 4 & 5 & 2 & 4 & 5 & 3.00 & 4 & 2 & 0.05 & 2.10 & 15 & 3.75 & 2.93 & 0.14 \\
\hline Rainfed herbaceus crop-pasture & 9.25 & 0.00 & 0 & 0.50 & 0 & 0 & 0 & 4 & 2 & 0 & 0 & 0 & 0 & 2.63 & 0 & 0 & 4 & 4 & 4 & 2 & 2 & 5 & 2.00 & 4 & 0 & 0.09 & 1.55 & 9 & 2.25 & 1.90 & 0.18 \\
\hline Rainfed herbaceous crop-fallow & 7.90 & 0.00 & 0 & 0.25 & 0 & 0 & 0 & 1 & 2 & 0 & 0 & 0 & 0 & 2.63 & 0 & 0 & 4 & 4 & 4 & 2 & 2 & 5 & 0.00 & 0 & 0 & 0.08 & 1.20 & 8 & 2.00 & 1.60 & 0.13 \\
\hline Irrigated herbaceous crop-horticulture & 41.08 & 4.00 & 4 & 0.92 & 5 & 0 & 0 & 2 & 2 & 0 & 0 & 2 & 0 & 3.13 & 1 & 2 & 4 & 3 & 5 & 2 & 3 & 5 & 3.00 & 4 & 2 & 0.41 & 2.30 & 15 & 3.75 & 3.03 & 1.24 \\
\hline Closed trees with shrubs & 14.73 & 4.00 & 4 & 0.58 & 0 & 0 & 0 & 0 & 4 & 1 & 2 & 0 & 0 & 4.75 & 4 & 5 & 5 & 5 & 5 & 4 & 5 & 5 & 2.00 & 4 & 0 & 0.15 & 2.65 & 12 & 3.00 & 2.83 & 0.42 \\
\hline Rural settlement-stables & 0.72 & 0.00 & 0 & 0.25 & 0 & 0 & 3 & 0 & 0 & 0 & 0 & 0 & 0 & 0.00 & 0 & 0 & 0 & 0 & 0 & 0 & 0 & 0 & 2.00 & 4 & 0 & 0.01 & 0.35 & , & 0.50 & 0.43 & 0.00 \\
\hline Artificial lakes or reservoirs & 0.18 & 0.00 & 0 & 0.00 & 0 & 0 & 0 & 0 & 0 & 0 & 0 & 0 & 0 & 0.63 & 1 & 0 & 0 & 0 & 0 & 4 & 0 & 0 & 2.00 & 4 & 0 & 0.00 & 0.45 & 3 & 0.75 & 0.60 & 0.00 \\
\hline Rural settlement-housing & 1.58 & 0.00 & 0 & 0.00 & 0 & 0 & 0 & 0 & 0 & 0 & 0 & 0 & 0 & 0.00 & 0 & 0 & 0 & 0 & 0 & 0 & 0 & 0 & 0.00 & 0 & 0 & 0.02 & 0.00 & 0 & 0.00 & 0.00 & 0.00 \\
\hline Bare soil/dirt roads & 0.64 & 0.00 & 0 & 0.00 & 0 & 0 & 0 & 0 & 0 & 0 & 0 & 0 & 0 & 0.75 & 0 & 1 & 1 & 1 & 1 & 1 & 1 & 0 & 0.00 & 0 & 0 & 0.01 & 0.30 & 6 & 1.50 & 0.9 & 0.01 \\
\hline Rainfed shrub plantation-bamboo & 2.07 & 0.00 & 0 & 0.67 & 0 & 0 & 0 & 0 & 4 & 4 & 0 & 0 & 0 & 3.75 & 3 & 4 & 4 & 4 & 4 & 4 & 2 & 5 & 3.00 & 4 & 2 & 0.02 & 2.20 & 12 & 3.00 & 2.60 & 0.05 \\
\hline Rainfead + irrigated agroforestry & 8.22 & 4.00 & 4 & 1.08 & 5 & 0 & 0 & 3 & 2 & 0 & 2 & 1 & 0 & 3.31 & 1 & 2 & 4 & 4 & 5 & 2 & 4 & 5 & 3.00 & 4 & 2 & 0.08 & 2.48 & 16 & 4.00 & 3.24 & 0.27 \\
\hline \multirow[t]{2}{*}{ Total \# of land cover classes } & \multirow[t]{2}{*}{12.00} & & & \multicolumn{19}{|c|}{ Colour code } & & \multirow{2}{*}{\multicolumn{4}{|c|}{$\begin{array}{l}\text { True Min Value } \\
\text { True Max Value } \\
\text { Normalized Min } \\
\text { Normalized Max }\end{array}$}} & A & 0 & \multirow[b]{2}{*}{ ASCI } & \multirow[b]{2}{*}{2.68} \\
\hline & & & & \multicolumn{3}{|c|}{$\begin{array}{c}\text { Low } \\
\text { capacity }\end{array}$} & \begin{tabular}{|c|}
0 \\
0.5 \\
0.8 \\
1 \\
\end{tabular} & \multicolumn{2}{|c|}{$\begin{array}{l}\text { Relevant } \\
\text { capacity }\end{array}$} & & $\begin{array}{l}\frac{1.3}{1.5} \\
1.8 \\
2 \\
\end{array}$ & \multicolumn{2}{|c|}{$\begin{array}{c}\text { Medium } \\
\text { high } \\
\text { capacity }\end{array}$} & \begin{tabular}{|c|}
2.3 \\
2.5 \\
2.8 \\
3 \\
\end{tabular} & \multicolumn{3}{|c|}{$\begin{array}{c}\text { High } \\
\text { capacity }\end{array}$} & \multicolumn{4}{|c|}{\begin{tabular}{|c|c|}
3.3 & \\
\cline { 1 - 1 } & Very high \\
\cline { 1 - 1 } & capacity \\
& \\
\end{tabular}} & \begin{tabular}{|l|}
4.3 \\
4.5 \\
4.8 \\
5
\end{tabular} & & & & & & $\begin{array}{l}\mathrm{B} \\
\mathrm{a} \\
\mathrm{b}\end{array}$ & $\begin{array}{c}20 \\
0 \\
5\end{array}$ & & \\
\hline
\end{tabular}




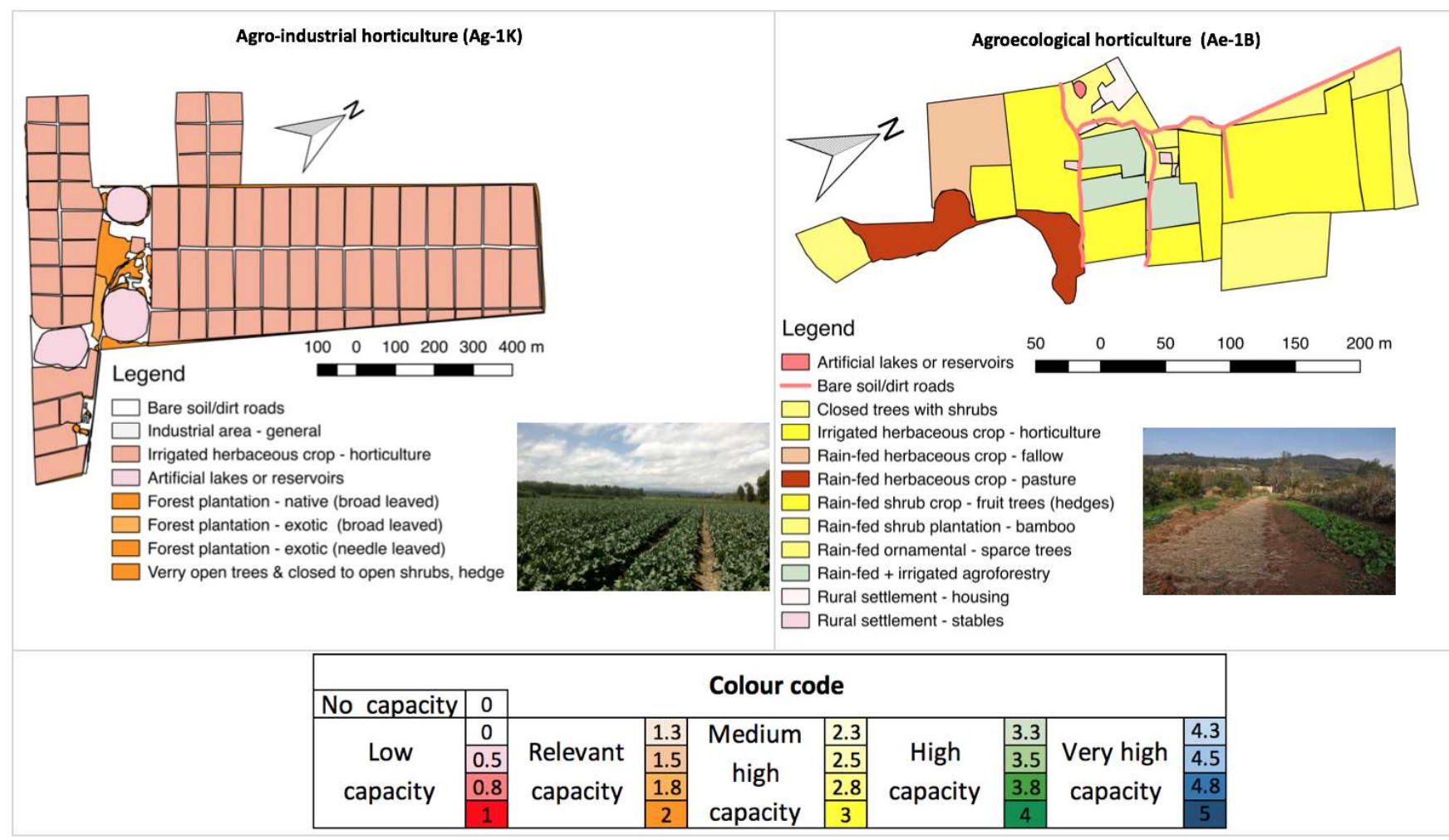

Figure 2: ASC Maps showing the agro-industrial horticulture farm in Kenya (Ag-1K) on the left and the agroecological horticulture farm in Bolivia (Ae-1B) on the right. The colour code uses the same scale as the rating of individual land cover classes; the intensity of each colour denotes decimals. E.g. the land cover class "Irrigated herbaceous crop" has an ASCMap value of 1.5 , so it is light red rather than dark red).

We have applied the ASC approach in 18 FBAs. In Tab 6. we summarize the results from four additional FBAs to illustrate the feasibility of applying the approach in different food systems. In terms of size, the smallest FBA to which we applied the ASC had half a hectare and the largest more than 4000 hectares. The lowest ASC Index value of 0.85 was identified in agro-industrial soybean production in Bolivia (Ag-3B); the highest value of 2.68 was found in agroecological horticulture in Bolivia (Ae-1B, presented above). This suggests that the agroecological FBA Ae-1B can provide approximately three times more FBA services than the agroindustrial FBA Ag-3B.

Table 6: Examples of application of ASC approach in different food systems in Bolivia and Kenya.

\begin{tabular}{c|cccc}
$\begin{array}{c}\text { Farm-based agro } \\
\text { ecosystem }\end{array}$ & $\begin{array}{c}\text { Agro-industrial, } \\
\text { Bolivia (Ag-3B) }\end{array}$ & $\begin{array}{c}\text { Indigenous, Bolivia } \\
\text { (In-1B) }\end{array}$ & $\begin{array}{c}\text { Small-scale, Kenya } \\
\text { (Sm-1K) }\end{array}$ & $\begin{array}{c}\text { Regional, Kenya } \\
\text { (Re-1K) }\end{array}$ \\
\hline Main crop products & Soybeans & Maize, beans & $\begin{array}{c}\text { Maize, beans, } \\
\text { potatoes }\end{array}$ & Wheat, barley \\
$\begin{array}{c}\text { Area (ha) } \\
\text { Land cover classes } \\
\text { (\#) }\end{array}$ & 39 & 1.79 & 0.5 & 4,500 \\
$\begin{array}{c}\text { Provided services } \\
\text { (\#) }\end{array}$ & 3 & 5 & 2 & 11 \\
ASC Index & 16 & 39 & 12 & 55 \\
\hline
\end{tabular}




\section{Discussion}

\subsection{Added value of the ASC approach}

The Agroecosystem Service Capacity (ASC) is a methodological approach that allows comparison of the capacity of farm-based agroecosystems - as central components of food systems - to provide farm-based agroecosystem services. Through this, the ASC approach can contribute to the assessment of environmental performance of food systems by tracing back the influence they have on the diversity of land cover classes and the related agroecosystem services. Using land cover classes to better understand human-nature interactions has gained importance in the scientific arena contributing to more informed decision-making processes. In unperturbed eco-systems, there is a certain homogeneity within land cover classes, although some local factors may be a source of variation. In perturbed agroecosystems, management plays an important role in determining the provision of agroecosystem services. Merging the concepts of FBAs and land cover classes in our conceptual and methodological framework has the advantage that the framework refers to a piece of landscape including its specific land cover classes, which are a result of management decisions and biophysical conditions. In this sense, it includes management implications. All FBAs potentially have the capacity to provide FBA services; however, their actual capacity to do so varies according to their biophysical characteristics and human management decisions, including inputs such as labour. Commonly, farms and their related patterns of land cover classes are measured by their annual yield of food or fibre (Biel 2016). The ASC approach that we propose here uses the yield of food, feed, or fibre and 19 other FBA services to assess and compare land cover classes in FBAs. The approach enables an integrated assessment of the FBA as a whole, looking beyond mere yields (Altieri 1983; Lescourret et al. 2015). For example, the two horticulture farms that we presented differ fundamentally in their management; one is agroecological and the other intensively managed cropland, which we refer to as agro-industrial.
Assessing the two FBAs' ASC Index showed that the management decisions taken in the agroecological FBA equipped it with twice the capacity of the agroindustrial FBA to provide FBA services. The ASC approach can help to shed light on the capacities of FBAs to provide FBA services. This can make it easier to redefine the roles FBAs play within a larger ecosystem or the planetary system. Thus, the approach can contribute to the scientific debate on food system sustainability.

Burkhard et al. (2009) proposed using land cover classes as a unit of analysis to assess the capacity of a landscape to provide ecosystem services. We add value to their method by taking it a step further and proposing: i) an option to assess and compare the capacity of agroecosystems to provide different agroecosystem services based on the land cover classes in FBAs; ii) a rating scale that is adapted to the types of data collectable at farm level and can also be applied by non-scientific actors; iii) an equation to estimate ASC per land cover class; iv) an equation to calculate ASC without factoring in area, to obtain values that can be used to map the ASCs of land cover classes in anFBA; v) an ASC Index to estimate an entire FBA's capacity to provide FBA services, in order to compare different FBAs.

Systems thinkers have mentioned that the whole of a system is more than the sum of its parts (Capra 1996). Likewise, the ASC Index is more than the sum of the ASCs of each land cover class since it integrates the strength $(\mathrm{Si})$, area $(\mathrm{Ai})$ and number of service $(\mathrm{Ni})$ that each land cover class can provide (see equation 1). Yet the ASC Index solely gives an indication of the capacity of the FBA to provide services: it is not a quantitative measure of this capacity. To include aspects that go beyond the sum of ASC values, the next step would be to map the interaction between land cover classes using social network theory as proposed by Griffon (2008). Due to time constraints, this has not been developed in the present study.

Sinare et al. (2016) proposed a method for classifying village landscapes into social-ecological patches (landscape units corresponding to local landscape perceptions) and for taking these patches 
as the basis for assessing provisioning ecosystem service and benefits to livelihoods. One of their recommendations was to include in the assessment other services, such as cultural and regulating ecosystem services (Sinare et al. 2016). The ASC we propose refers to provisioning, regulating/ maintenance, cultural, and supporting services in the context of FBA. It could be adapted and applied to study the capacity of village landscapes to provide FBA services.

The ASC approach evaluates the FBA service flow related to land cover classes during one normal year. Burkhard et al. (2012) identify two other types of ecosystem service: i) ecosystem service potentials, defined as the hypothetical maximum yield of selected ecosystem services; and ii) demand for ecosystem services, defined as the ecosystem goods and services consumed or used in a particular area over a given time. The ASC approach does not include an assessment of these, because, in our approach, if a land cover depends on external services, this means it provides few or no FBA services. Hence, the FBA will demand more services than it can provide. In terms of the hypothetical maximum, a new scale would have to be developed in the ASC Toolbox to assess the hypothetical maximum and compare it to the actual flow. However, given the complexity of defining the hypothetical maxima for the different FBA services, we considered it more straightforward to compare the actual flow of FBA services.

\subsection{Challenges and prospects for the ASC approach}

We implemented the ASC approach in a set of situations in which we faced several challenges. The main challenge while developing the tool was to strike a balance between high quality scientific data and information that is feasible to be collected under field conditions in Bolivia or Kenya. Extensive field work led us to the compromise presented here (see rating scale in ASC Toolbox in Annex). Nevertheless, both the scale and the tools for assessing capacity to provide FBA services could be further improved based on empirical application of the tool in more situations and additional research on specific FBA services.

FBA services are difficult to put into entirely quantitative data. Consequently, we used different approaches to collect data on the capacity of each land cover class to provide FBA services. The data sources ranged from quantitative and qualitative indicators toactivity-based proxies and vegetation cover proxies (see section 3.3). Although we tried to reduce uncertainty, each data source entails a level of uncertainty. In terms of sensibility to single variables, in the ASC all land cover classes and all FBA services are given the same level of importance. The ASC was tested in 18 FBAs in different contexts and constantly yielded coherent results and demonstrated its robustness. However, it is important to underline that the ASC Index provides an indication - and not an absolute quantitative value - of an FBA's ASC. Beyond the value itself the story and analysis that can be built around the value, showed to be important as well.

Critics may argue that the ASC approach simplifies the complex interactions in FBAs by reducing them to a set of land cover classes and FBA services. However, the complex interactions of biophysical aspects in FBAs are considered via the FBA services that are selected for assessment e.g. via soil formation and water purification. The type and number of FBA services included in the assessment can be adapted to the given local context so as to consider more or fewer biophysical aspects of the FBA.

End users of the ASC approach may face the following challenges: i) its application is time-consuming and ii) rating land cover classes is not easy and requires expert judgement even though we have tried to make the rating scale as precise as possible.

The ASC approach and the 20 FBA services of the ASC Toolbox focus solely on food systems' production activities, and not on other food system stages such as input provision, processing, transport, or retail. This is at odds with a more coherent food system approach. However, assessing a food system's 
production stage is the first - and probably most important - step, because this stage shapes the structure of land cover across a large area and accounts for a positive or negative balance of the food system's capacity to provide FBA services. Nevertheless, an important next step would be to adapt the ASC Toolbox for applicability to the entire supply chains of food systems. This would mean e.g. assessing to what degree the extraction of gas, oil, or minerals used for producing mineral fertilizers or pesticides affects the FBAs' ASC and the overall balance of an agro-industrial food system in terms of its capacity to provide FBA services.

The results of the ASC approach can provide a basis for further discussion on food system sustainability. For example, on defining a minimum, in terms of quality and composition, of FBA services that land cover classes of FBAs should provide. If we recognize that farms are much more than biomass producers, we can give them more responsibility as well as regulations that make them provide more FBA services. We can also acknowledge their contributions to local and global well-being, e.g. by reducing their taxes or introducing other incentives adapted to local contexts.

\section{Conclusions}

In the face of today's socio-environmental challenges, humanity cannot afford to have farm-based agroecosystems that only produce biomass. It is not useful to concentrate on environmental challenges as individual variables: The challenge in assessing the sustainability of agriculture lies in developing assessment methods that take into consideration different variables such as ecosystem services (Therond et al. 2017). We have demonstrated here that the ASC approach is such a multi-criteria method. It is suited for use in the global South and can be applied with primary data collected directly from farmers. The ASC approach provides a means of comparing different FBAs considering a total of 20 FBA services: twelve provisioning, eight regulating, two cultural, and one supporting FBA services. The results are presented per land cover class, showing which land cover classes in a given FBA have the highest capacity to provide FBA services. Additionally, the ASC Index provides one value for the whole FBA, enabling comparison between different FBAs- which may be part of different food systems. Decisionmakers can use ASC data to make more informed decisions on which food systems to promote and which not.

The ASC approach is mostly grounded in literature on ecosystem services. Accordingly, the social dimension of FBAs needs to be explored in more detail. Examples might include their capacity to provide work opportunities and safe working environments. Finally, the ASC approach is being empirically applied in additional FBAs in Bolivia and Kenya in order to further test its applicability and to encourage decision-makers to promote food systems whose FBAs provide more FBA services.

\section{Acknowledgements}

This work is part of the project "Towards food sustainability: Reshaping the coexistence of different food systems in South America and Africa", under the Swiss Programme for Research on Global Issues for Development ( $\mathrm{r} 4 \mathrm{~d}$ programme). As such, it is funded by the Swiss Agency for Development and Cooperation and the Swiss National Science Foundation [Grant number 400540_152033], with additional support from the Centre for Development and Environment (CDE), University of Bern, Switzerland. This work would not have been possible if farmers in Bolivia and Kenya had not opened their doors and shared their time with us: we warmly thank them all. We also thank people from Agroecología Universidad Cochabamba (AGRUCO), Cochabamba, Bolivia; and the Centre for Training and Integrated Research in Arid and Semiarid Lands Development (CETRAD), Nanyuki, Kenya. Thanks to all project colleagues, friends, and family for sharing their time, contacts, knowledge, and experiences; to the two anonymous reviewers for their valuable comments and suggestions; and to Tina Hirschbuehland Marlène Thibault for editing this manuscript. 


\section{References}

Altieri, M. (1983). Agroecología, bases cientificas de la agricultura alternativa (M. Altieri Ed. 1st ed.). Santiago, Chile: Centro de Estudios en Tecnoligias Apropiada para America Latina.

Altieri, M. (1999). The ecological role of biodiversity in agroecosystems. Agriculture, Ecosystems \& Environment, 74 (1-3). DOI:10.1016/S01678809(99)00028-6.

Biel, R. (2016). Sustainable Food Systems: UCL Press. DOI: 10.14324/111.9781911307099

Burkhard, B.; Kandziora, M.; Hou, Y., \& Müller, F. (2014). Ecosystem service potentials, flows and demands-concepts for spatial localization, indication and quantification. Landscape Online, 34, 1-32. DOI: 10.3097/LO.201434

Burkhard, B.; Kroll, F.; Müller, F., \& Windhorst, W. (2009). Landscapes' capacities to provide ecosystem services-a concept for land-cover based assessments. Landscape Online, 15 (1), 1-22. DOI: 22.10.3097/LO.200915.

Burkhard, B.; Kroll, F.; Nedkov, S., \& Müller, F. (2012). Mapping ecosystem service supply, demand and budgets. Ecological Indicators, 21, 17-29. DOI:10.1016/j.ecolind.2011.06.019.

Capra, F. (1996). The web of life: Audio Renaissance Tapes

Cardinale, B. J.; Duffy, J. E.; Gonzalez, A.; Hooper, D. U.; Perrings, C.; Venail, P.; Narwani, A.; Mace, G. M.; Tilman, D.; Wardle, D. A.; Kinzig, A. P.; Daily, G. C.; Loreau, M.; Grace, J. B.; Larigauderie, A.; Srivastava, D. S., \& Naeem, S. (2012). Biodiversity loss and its impact on humanity. Nature, 486, 59. DOI: $10.1038 /$ nature11148.

Carvalheiro, G.; Seymour, L.; Veldtman, R., \& Nicolson, W. (2010). Pollination services decline with distance from natural habitat even in biodiversityrich areas. Journal of Applied Ecology, 47(4), 810820. DOI: 10.1111/j.1365-2664.2010.01829.x
Colonna, P.; Fournier, S., \& Touzard, J.-M. (2013). Food Systems, in: Food System Sustainability: Insights from DuALIne (C. Esnouf; M. Russel, \& N. Bricas Eds.): Cambridge University Press.

Conway, G. R. (1985). Agroecosystem analysis. Agricultural Administration, 20(1), 31-55. DOI:10.1016/0309-586X(85)90064-0.

Conway, G. R. (1987). The properties of agroecosystems. Agricultural Systems, 24(2), 95117. DOI: $10.1016 / 0308-521 X(87) 90056-4$.

Crutzen, P. J., \& Stoermer, E. F. (2011). The „Antrhopocene“. IGBP Newsletter, 739-761. DOI: 10.1007/s13280-011-0185-x.

De Groot, R. S.; Alkemade, R.; Braat, L.; Hein, L., \& Willemen, L. (2010). Challenges in integrating the concept of ecosystem services and values in landscape planning, management and decision making. Ecological Complexity, 7(3), 260-272. DOI: 10.1016/j.ecocom.2009.10.006.

De Groot, R. S.; Wilson, M., \& Boumans, R. M. J. (2002). A typology for the classification, description and valuation of ecosystem functions, goods and services. Ecological Economics, 41, 393-408. DOI: 10.1016/S0921-8009(02)00089-7.

De la Vega-Leinert, A. (2014). Can UNESCO Biosphere Reserves bridge the apparent gap between land sharing and land sparing. Global Land Project NEWS 10, 21-24.

De la Vega-Leinert, A., \& Clausing, P. (2016). Extractive Conservation: Peasant Agroecological Systems as New Frontiers of Exploitation? Environment and Society, 7(1), 50-70. DOI: 10.3167/ares.2016.070104.

Di Gregorio, A. (2016). Land Cover Classification System: Software version 3 (F. a. A. O. o. t. U. Nations Ed.). Rome: Food and Agricultur Organization of the United Nations 
Dominati, E. J.; Robinson, D. A.; Marchant, S. C.; Bristow, K. L., \& Mackay, A. D. (2014). Natural Capital, Ecological Infrastructure, and Ecosystem Services in Agroecosystems A2 - Alfen, Neal K. Van. Oxford: Academic Press, 245-264. DOI: 10.1016/B978-0-444-52512-3.00243-6.

Duru, M.; Therond, O., \& Fares, M. h. (2015). Designing agroecological transitions; A review. Agronomy for Sustainable Development, 35(4), 1237-1257. DOI: 10.1007/s13593-015-0318-x.

Ericksen, P. (2008). Conceptualizing food systems for global environmental change research. Global Environmental Change, 18(1), 234-245. DOI: 10.1016/j.gloenvcha.2007.09.002.

Ericksen, P.; Said, M.; Leeuw, J. d.; Silvestri, S.; Zaibet, L.; Kifugo, S.; Sijmons, K.; Kinoti, J.; Nganga, L., \& Landsberg, F. (2011). Mapping and valuing ecosystem services in the Ewaso $\mathrm{Ng}^{\prime}$ iro watershed.

Erik, N.; Guillermo, M.; James, R.; Stephen, P.; Heather, T.; DRichard, C.; MA, C. K.; C, D. G.; Joshua, G.; M, K. P.; Eric, L.; Robin, N.; H, R. T., \& MRebecca, S. (2009). Modeling multiple ecosystem services, biodiversity conservation, commodity production, and tradeoffs at landscape scales. Frontiers in Ecology and the Environment, 7(1), 4-11. DOI:10.1890/080023.

Fang, X.; Zhao, W.; Fu, B., \& Ding, J. (2015). Landscape service capability, landscape service flow and landscape service demand: A new framework for landscape services and its use for landscape sustainability assessment. Progress in Physical Geography, 39(6), 817-836. DOI: 10.1177/0309133315613019.

Fischer, J.; Abson, D. J.; Butsic, V.; Chappell, M. J.; Ekroos, J.; Hanspach, J.; Kuemmerle, T.; Smith, H. G., \& Wehrden, H. (2014). Land sparing versus land sharing: moving forward. Conservation Letters, 7(3), 149-157. DOI: 10.1111/j.14668238.2007.00287.x
Fischer, J.; Brosi, B.; Daily, G. C.; Ehrlich, P. R.; Goldman, R.; Goldstein, J.; Lindenmayer, D. B.; Manning, A. D.; Mooney, H. A.; Pejchar, L.; Ranganathan, J., \& Tallis, H. (2008). Should agricultural policies encourage land sparing or wildlife-friendly farming? Frontiers in Ecologyand the Environment, 6(7), 380-385. DOI:10.1890/070019.

Foley, J. A.; DeFries, R.; Asner, G. P.; Barford, C.; Bonan, G.; Carpenter, S. R.; Chapin, F. S.; Coe, M. T.; Daily, G. C.; Gibbs, H. K.; Helkowski, J. H.; Holloway, T.; Howard, E. A.; Kucharik, C. J.; Monfreda, C.; Patz, J. A.; Prentice, I. C.; Ramankutty, N., \& Snyder, P. K. (2005). Global Consequences of Land Use. Science, 309(5734), 570-574. DOI: 10.1126/ science. 1111772.

Foley, J. A.; Ramankutty, N.; Brauman, K. A.; Cassidy, E. S.; Gerber, J. S.; Johnston, M.; Mueller, N. D.; O/'Connell, C.; Ray, D. K.; West, P. C.; Balzer, C.; Bennett, E. M.; Carpenter, S. R.; Hill, J.; Monfreda, C.; Polasky, S.; Rockstrom, J.; Sheehan, J.; Siebert, S.; Tilman, D., \& Zaks, D. P. M. (2011). Solutions for a cultivated planet. Nature, 478(7369), 337342. DOI: $10.1038 /$ nature10452.

Food and Agriculture Organization; International Fund for Agricultural Development; United Nations International Children's Emergency Fund; World Food Programme, \& World Health Organization. (2017). The State of Food Security and Nutrition in the World 2017. Building resilience for peace and food security. http:// www.fao.org/3/a-17695e.pdf (Date 02.03.2018).

Food and Agriculture Organization of the United Nations. (2003, 11.10.2016). Africover Multipurpose Land Cover Database for Kenya. http://www.fao.org/geonetwork/srv/en/ main. home?uuid=7eae9108-3032-4b5c-9fd1c5f0891ba01f (Date 11.10.2016)

Food and agriculture organization of the United Nations. (2012). Handbook for participatory socioeconomic evaluation of polinator-freindly practices. http://www.fao.org/3/a-i2442e.pdf (Date 09.11.2016). 
Food and agriculture organization of the United Nations. (2013). SAFA, Sustainability assessment of food and agriculture systems Indicators. http://www.fao.org/fileadmin/templates/nr/ sustainability_pathways/docs/SAFA_Indicators_ final_19122013.pdf (Date 05.05.2015).

Fouilleux, E.; Bricas, N., \& Alpha, A. (2017). 'Feeding 9 billion people': global food security debates and the productionist trap. Journal of European Public Policy, 24(11), 1658-1677. DOI 10.1080/13501763.2017.1334084.

Garbach, K.; Milder, J.; Montenegro, M.; Karp, D., \& DeClerck, F. (2014). Biodiversity and ecosystem services in agroecosystems. Encyclopedia of Agriculture and Food Systems, 21-40. DOI: 10.1016/B978-0-444-52512-3.00013-9.

García-Nieto, A. P.; García-Llorente, M.; IniestaArandia, I., \& Martín-López, B. (2013). Mapping forest ecosystem services: From providing units to beneficiaries. Ecosystem Services, 4, 126-138. DOI: 10.1016/j.ecoser.2013.03.003.

Gliessman, S. R. (2007). Agroecology: The Ecology of Sustainable Food Systems (Second ed.). Boca Raton, Florida: CRC

Green, R. E.; Cornell, S. J.; Scharlemann, J. P., \& Balmford, A. (2005). Farming and the fate of wild nature. Science, 307(5709), 550-555. DOI: 10.1126/science.1106049

Griffon, D. (2008). Estimación de la biodiversidad en agroecología. Agroecología, 3, 6, 25-31.

Haines-Young, R., \& Potschin, M. (2013). Common international classification of ecosystem services (CICES): consultation on version 4, AugustDecember 2012. https://cices.eu/content/ uploads/sites/8/2012/07/CICES-V43_RevisedFinal_Report_29012013.pdf (Date 13.11.2017)

Hart, R. D. (1985). Conceptos básicos sobre agroecosistemas. Turrailba, Costa Rica: Centro Agronomico tropical de investigacion y enseñanza
Horlings, L. G., \& Marsden, T. K. (2011). Towards the real green revolution? Exploring the conceptual dimensions of a new ecological modernisation of agriculture that could 'feed the world'. Global Environmental Change, 21(2), 441-452. DOI: 10.1016/j.gloenvcha.2011.01.004.

IAASTD International Assessment of Agricultural Knowledge Science and Technology for Development. (2009). Agriculture at a Crossroads: International Assessment of Agricultural Knowledge, Science and Technology for Development: Global Report: IAASTD

Jacobi, J.; Schneider, M.; Bottazzi, P.; Pillco, M.; Calizaya, P., \& Rist, S. (2015). Agroecosystem resilience and farmers' perceptions of climate change impacts on cocoa farms in Alto Beni, Bolivia. Renewable Agriculture and Food Systems, 30(02), 170-183. DOI: 10.1017/S174217051300029X.

Koschke, L.; Fürst, C.; Frank, S., \& Makeschin, F. (2012). A multi-criteria approach for an integrated land-cover-based assessment of ecosystem services provision to support landscape planning. Ecological Indicators, 21, 54-66. DOI: 10.1016/j. ecolind.2011.12.010.

Kyösti, A., \& Olli, S. (2013). Classification of Agricultural Ecosystem Goods and Services in Finland. http://www.ptt.fi/media/wp/tp155.pdf (Date 13.09.2017).

Lee, J. S. H.; Garcia-Ulloa, J.; Ghazoul, J.; Obidzinski, K.; Koh, L. P., \& Jones, J. (2014). Modelling environmental and socio-economic trade-offs associated with land-sparing and land-sharing approaches to oil palm expansion. Journal of Applied Ecology, 51(5). DOI: 10.1111/13652664.12286.

Lescourret, F.; Magda, D.; Richard, G.; AdamBlondon, A.-F.; Bardy, M.; Baudry, J.; Doussan, I.; Dumont, B.; Lefèvre, F.; Litrico, I.; Martin-Clouaire, R.; Montuelle, B.; Pellerin, S.; Plantegenest, M.; Tancoigne, E.; Thomas, A.; Guyomard, H., \& Soussana, J.-F. (2015). A social-ecological approach to managing multiple agro-ecosystem services. Current Opinion in Environmental Sustainability, 14, 68-75. DOI: 10.1016/j.cosust.2015.04.001. 
Lin, B. B. (2011). Resilience in agriculture through crop diversification: adaptive management for environmental change. BioScience, 61(3), 183193.DOI: 10.1525/bio.2011.61.3.4.

López-ridaura, S.; Keulen, H. V.; Ittersum, M. K. v., \& Leffelaar, P. A. (2005). Multiscale Methodological Framework to Derive Criteria and Indicators for Sustainability Evaluation of Peasant Natural Resource Management Systems. Environment, Development and Sustainability, 7(1), 51-69. DOI: 10.1007/s10668-003-6976-x.

Ma, F.; Eneji, A. E., \& Liu, J. (2015). Assessment of ecosystem services and dis-services of an agro-ecosystem based on extended emergy framework: A case study of Luancheng county, North China. Ecological Engineering, 82, 241-251. DOI: 10.1016/j.ecoleng.2015.04.100.

Malinga, R.; Gordon, L. J.; Jewitt, G., \& Lindborg, R. (2015). Mapping ecosystem services across scales and continents - A review. Ecosystem Services, 13(Supplement C), 57-63. DOI: 10.1016/j. ecoser.2015.01.006.

Manning, P.; van der Plas, F.; Soliveres, S.; Allan, E.; Maestre, F. T.; Mace, G.; Whittingham, M. J., \& Fischer, M. (2018). Redefining ecosystem multifunctionality. Nature Ecology \& Evolution, 2(3), 427-436. DOI: 10.1038/s41559-017-0461-7.

Mastrangelo, M. E.; Weyland, F.; Villarino, S. H.; Barral, M. P.; Nahuelhual, L., \& Laterra, P. (2014). Concepts and methods for landscape multifunctionality and a unifying framework based on ecosystem services. Landscape Ecology, 29(2), 345-358. DOI: 10.1007/s10980-013-99599.

Millennium Ecosystem Assessment, M. (2005). Ecosystems and human well-being: Our human planet. Summary for decision-makers. (I. Press Ed.). Washington, DC

Ministry of Agriculture. (2009). The Agriclurue Act (Cap 318) Agriculture (Farm Forestry) Rules, 2009. http://www4.total.fr/pdf/AMO/Kenya/ ecochallenge/the\%20expert\%20corner/FarmForestry-Rules.pdf (Date 10.03.2017).
Peano, C.; Migliorini, P., \& Sottile, F. (2014). A methodology for the sustainability assessment of agri-food systems: an application to the Slow Food Presidia project. Ecology and Society, 19(4). DOI: 10.5751/ES-06972-190424.

Perfecto, I.; Vandermeer, J., \& Wright, A. (2009). Nature's matrix: linking agriculture, conservation and food sovereignty. New York, USA: Earthscan

Petter, M.; Mooney, S.; Maynard, S. M.; Davidson, A.; Cox, M., \& Horosak, I. (2013). A Methodology to Map Ecosystem Functions to Support Ecosystem Services Assessments. Ecology and Society, 18(1). DOI: 10.5751/ES-05260-180131.

Phalan, B.; Onial, M.; Balmford, A., \& Green, R. E. (2011). Reconciling food production and biodiversity conservation: land sharing and land sparing compared. Science, 333(6047), 12891291. DOI: $10.1126 /$ science. 1208742

Porter, J.; Costanza, R.; Sandhu, H.; Sigsgaard, L., \& Wratten, S. (2009). The Value of Producing Food, Energy, and Ecosystem Services within an AgroEcosystem. AMBIO: A Journal of the Human Environment, 38(4), 186-193. DOI: 10.1579/00447447-38.4.186.

Power, A. G. (2010). Ecosystem services and agriculture: tradeoffs and synergies. Philosophical Transactions of the Royal Society B: Biological Sciences, 365(1554), 2959-2971. DOI: 10.1098/ rstb.2010.0143.

Rist, S., \& Jacobi, J. (2015). Selection of Food Systems in Bolivia and Kenya and Methods of Analysis. Towards Food Sustainability (Working Paper No. 2). Bern, Switzerland.

Rockstrom, J.; Steffen, W.; Noone, K.; Persson, A.; Chapin, F. S.; Lambin, E. F.; Lenton, T. M.; Scheffer, M.; Folke, C.; Schellnhuber, H. J.; Nykvist, B.; de Wit, C. A.; Hughes, T.; van der Leeuw, S.; Rodhe, H.; Sorlin, S.; Snyder, P. K.; Costanza, R.; Svedin, U.; Falkenmark, M.; Karlberg, L.; Corell, R. W.; Fabry, V. J.; Hansen, J.; Walker, B.; Liverman, D.; Richardson, K.; Crutzen, P., \& Foley, J. A. (2009). A safe operating space for humanity. Nature, 461 (7263), 472-475. DOI: 10.1038/461472a 
Schutter, O. D. (2014). Final report: The transformative potential of the right to food. https://business-humanrights.org/en/ report-by-un-special-rapporteur-on-rightto-food-says-current-food-systems-efficientonly-at-maximizing-agribusiness-profits-fails-toactually-feed-the-hungry?dateorder=dateasc (Date 11.12.2016)

Sinare, H.; Gordon, L. J., \& Enfors Kautsky, E. (2016). Assessment of ecosystem services and benefits in village landscapes - A case study from Burkina Faso. Ecosystem Services, 21(Part A), 141-152. DOI: 10.1016/j.ecoser.2016.08.004.

Steffen, W.; Persson, Å.; Deutsch, L.; Zalasiewicz, J.; Williams, M.; Richardson, K.; Crumley, C.; Crutzen, P.; Folke, C.; Gordon, L.; Molina, M.; Ramanathan, V.; Rockström, J.; Scheffer, M.; Schellnhuber, H., \& Svedin, U. (2011). The Anthropocene: From Global Change to Planetary Stewardship. AMBIO, 40(7), 739-761. DOI: 10.1007/s13280-011-0185-x.

Šūmane, S.; Kunda, I.; Knickel, K.; Strauss, A.; Tisenkopfs, T.; Rios, I. d. I.; Rivera, M.; Chebach, T., \& Ashkenazy, A. (2018). Local and farmers' knowledge matters! How integrating informal and formal knowledge enhances sustainable and resilient agriculture. Journal of Rural Studies, 59, 232-241. DOI: 10.1016/j.jrurstud.2017.01.020.

Therond, O.; Duru, M.; Roger-Estrade, J., \& Richard, G. (2017). A new analytical framework of farming system and agriculture model diversities. A review. Agronomy for Sustainable Development, 37(3), 1-24. DOI: 10.1007/s13593-017-0429-7

United Nations. (1992). Convention on Biologial Diversity. http://biodiversitya-z.org/content/ ecosystem (Date 02.01.2018).

Villamagna, A. M.; Angermeier, P. L., \& Bennett, E. M. (2013). Capacity, pressure, demand, and flow: A conceptual framework for analyzing ecosystem service provision and delivery. Ecological Complexity, 15(Supplement C), 114-121. DOI: 10.1016/j.ecocom.2013.07.004.
Wiggering, H.; Weißhuhn, P. \& Burkhard, B. (2016). Agrosystem Services: An Additional Terminology to Better Understand Ecosystem Services Delivered by Agriculture. Landscape Online 49, 1-15. DOI: 10.3097/LO.201649.

Zhang, W.; Ricketts, T. H.; Kremen, C.; Carney, K., \& Swinton, S. M. (2007). Ecosystem services and dis-services to agriculture. Ecological Economics, 64(2), 253-260. DOI: 10.1016/j. ecolecon.2007.02.024. 


\section{Landscape Online}

LANDSCAPE ONLINE 64:1- 48(2018), DOI 10.3097/LO.201864

Page 26

\section{Annex}

Table 1: ASC Toolbox: Description of Farm-based Agroecosystem Service (FBA SERVICES) class, definition, potential service providing units, detailed description, guiding questions for assessment of land cover class capacity to provide the service, and rating scale for assessment.

\begin{tabular}{|c|c|c|c|c|}
\hline AGROECOSYSTEM CLASS & DEFINITION & $\begin{array}{l}\text { LAND COVER } \\
\text { CLASS }\end{array}$ & DESCRIPTION & GUIDING QUESTION AND RATING SCALE \\
\hline $\begin{array}{l}\text { Types of FBA services } \\
\text { that can be provided by } \\
\text { the land cover class }\end{array}$ & $\begin{array}{l}\text { Specific } \\
\text { services/functions } \\
\text { that the land cover } \\
\text { class can provide in a } \\
\text { year }\end{array}$ & $\begin{array}{l}\text { Land cover } \\
\text { class that can } \\
\text { provide FBA } \\
\text { services }\end{array}$ & $\begin{array}{l}\text { Through suggested } \\
\text { indicators in scientific } \\
\text { literature } \\
\text { Indicator: } \\
\text { Measurement or value } \\
\text { used to assess land cover } \\
\text { class capacity to provide a } \\
\text { specific service in one } \\
\text { year using qualitative and } \\
\text { quantitative data }\end{array}$ & $\begin{array}{l}\text { General question used to generate data according to a previously defined } \\
\text { indicator } \\
\text { Scale: } \\
\text { Rating used to assess the land cover class to provide a service according to } \\
\text { a defined indicator. The scale has been standardized by rating } \\
\text { comparatively all the results with best- and worst-case scenarios within all } \\
\text { land cover classes of the food systems in each country } \\
\text { Types of scales (see section 3.3): } \\
\text { 1-Quanitative: Refers to maximum and minimum quantities of certain } \\
\text { goods } \\
\text { 2- Qualitative: Refers to descriptions of the capacity a land cover class has } \\
\text { to provide FBA services } \\
\text { 2-Activity based: Proxies' activities (identified in literature) that can } \\
\text { promote or hinder the capacity to provide specific FBA services by different } \\
\text { land cover classes } \\
\text { 3-Vegetation cover. For natural and semi-natural land cover classes, the }\end{array}$ \\
\hline
\end{tabular}




\section{Landscape Online}

LANDSCAPE ONLINE 64:1- 48(2018), DOI 10.3097/LO.201864

Page 27

\begin{tabular}{|c|c|c|c|c|}
\hline & & & & $\begin{array}{l}\text { capacity to provide specific FBA services according to type of vegetation } \\
\text { cover }\end{array}$ \\
\hline \multicolumn{5}{|c|}{$\begin{array}{l}\text { SECTION: PROVISIONING SERVICES } \\
\text { DIVISION: NUTRITION (Haines-Young \& Potschin,2013) } \\
\text { GROUP: BIOMASS }\end{array}$} \\
\hline Food crops & $\begin{array}{l}\text { Provisioning of edible } \\
\text { plants }\end{array}$ & $\begin{array}{l}\text { Cropland, } \\
\text { gardens, fruit } \\
\text { plantations } \\
\text { (Burkhard et } \\
\text { al. 2009) } \\
\text { (Burkhard et } \\
\text { al. 2014) }\end{array}$ & $\begin{array}{l}\text { Harvested crops: t/ha/yr; } \\
\mathrm{kJ} / \mathrm{ha} / \mathrm{yr} \text { or } \$ / \mathrm{yr} / \mathrm{ha} \\
\text { Indicator: } \\
\text { Quantitative } \\
\text { Humid harvest: } \mathrm{t} / \mathrm{ha} / \mathrm{yr} \\
\text { (Burkhard et al. 2009) } \\
\text { (Burkhard et al. 2014) }\end{array}$ & $\begin{array}{l}\text { How much food crop can the land cover class produce? } \\
\text { Specific questions: } \\
\text { How much produce can this land cover class provide per year? } \\
\text { Scale } \\
\text { 5-Very high capacity: }>20 \mathrm{t} / \mathrm{ha} / \mathrm{yr} \\
\text { 4-High capacity: } 15-20 \mathrm{t} / \mathrm{ha} / \mathrm{yr} \\
\text { 3-Medium capacity: } 10-15 \mathrm{t} / \mathrm{ha} / \mathrm{yr} \\
\text { 2-Relevant capacity: } 5-10 \mathrm{t} / \mathrm{ha} / \mathrm{yr} \\
\text { 1-Low capacity: } 1-5 \mathrm{t} / \mathrm{ha} / \mathrm{yr} \\
0 \text {-No capacity: }<1 \mathrm{t} / \mathrm{ha} / \mathrm{yr}\end{array}$ \\
\hline Wild food and resources & \begin{tabular}{|l|} 
Fruits, mushrooms, \\
plants, wild animals, \\
fish \\
(Burkhard et al. 2009) \\
(Burkhard et al. 2014)
\end{tabular} & $\begin{array}{l}\text { Forests, } \\
\text { grasslands, } \\
\text { agricultural } \\
\text { fields, } \\
\text { waterbodies, } \\
\text { water courses } \\
\text { (Burkhard et } \\
\text { al. 2009) } \\
\text { (Burkhard et }\end{array}$ & $\begin{array}{l}\text { Number of collected types } \\
\text { of mushrooms, plants, } \\
\text { honey, game, and fish: } \\
\mathrm{kg} / \mathrm{ha} / \mathrm{yr} \\
\text { Indicators } \\
\text { Qualitative } \\
\text { Frequency and amount of } \\
\text { food/products consumed } \\
\text { (Burkhard et al. 2009) }\end{array}$ & $\begin{array}{l}\text { How many different types of wild food can the land cover class provide? } \\
\text { Specific questions: } \\
\text { Which and how many types of food do you gather or hunt from the land } \\
\text { cover classes (plants, fruits, honey, and game or fish collected), andhow } \\
\text { often do you consume them? } \\
\text { Scale } \\
\text { 5-Very high capacity: > } 5 \text { different types of food consumed every day } \\
\text { 4-High capacity: 2-5 types of food consumed once a week } \\
\text { 3-Medium capacity: Some types of food consumed once a month }\end{array}$ \\
\hline
\end{tabular}




\section{Landscape Online}

LANDSCAPE ONLINE 64:1- 48(2018), DOI 10.3097/LO.201864

Page 28

\begin{tabular}{|c|c|c|c|c|}
\hline & & al. 2014) & (Burkhardet al. 2014) & $\begin{array}{l}\text { 2-Relevant capacity: Few types of food we sometimes consume in the year } \\
\text { 1-Low capacity: Very few types of food that we rarely consume } \\
\text { 0-No capacity: No products are consumed }\end{array}$ \\
\hline Livestock (domestic) & $\begin{array}{l}\text { Domestic animals for } \\
\text { nutrition and by- } \\
\text { products (dairy, wool, } \\
\text { eggs, meat) } \\
\text { (Burkhard et al. 2009) } \\
\text { (Burkhard et al. 2014) }\end{array}$ & $\begin{array}{l}\text { Pastures, } \\
\text { farms, stables, } \\
\text { grassland, } \\
\text { agroforestry } \\
\text { (Burkhard et } \\
\text { al. 2009) } \\
\text { (Burkhard et } \\
\text { al. 2014) }\end{array}$ & $\begin{array}{l}\text { Respective animal } \\
\text { products } \mathrm{t} / \mathrm{ha} / \mathrm{yr} ; \mathrm{kJ} / \mathrm{ha} / \mathrm{yr} \\
\text { Indicators } \\
\text { Quantitative } \\
\text { Heads/ha, tn/yr, It/yr } \\
\text { Qualitative } \\
\text { Importance of the activity } \\
\text { in the land cover class } \\
\text { (Burkhard et al. 2009) } \\
\text { (Burkhardet al. 2014) }\end{array}$ & $\begin{array}{l}\text { How capable is the land cover class of providing livestock products? } \\
\text { Specific questions } \\
\text { How much livestock or livestock by-products can the land cover provide? } \\
\text { Which and how many livestock do you have? } \\
\text { How much of your food do you get from your livestock? } \\
\text { Which \% of your income comes from livestock? } \\
\text { How many livestock by-products are produced and sold per year (tn/yr, } \\
\text { kg/yr, or It/yr)? } \\
\text { Scale } \\
\text { 5-Very high capacity: Intensive livestock production (100\% of income). } \\
\text { Large livestock (cattle, sheep, and goats) or small livestock (poultry, pigs } \\
\text { and rabbits) } \\
\text { 4-High capacity: Main activity extensive livestock (>80\% of income). Large } \\
\text { livestock 6-8 heads/ha (cattle, sheep, and goats) or small livestock >100 } \\
\text { (poultry, pigs, and rabbits) } \\
\text { 3-Medium capacity: Mixed land cover class livestock/crop (50-50\% of } \\
\text { income), extensive livestock, regularly selling livestock products. Large } \\
\text { livestock 2-6 heads/ha (cattle, sheep, and goats) or small livestock >50 } \\
\text { (poultry, pigs, and rabbits) } \\
\text { 2-Relevant capacity: Mixed land cover class livestock/crop (40-60\% of } \\
\text { income), extensive livestock, sometimes livestock products are sold. Large }\end{array}$ \\
\hline
\end{tabular}




\section{Landscape Online}

LANDSCAPE ONLINE 64:1- 48(2018), DOI 10.3097/LO.201864

Page 29

\begin{tabular}{|c|c|c|c|c|}
\hline & & & & $\begin{array}{l}\text { livestock 2-6 heads/ha (cows, sheep, and goats) or small livestock 10-50 } \\
\text { (poultry, pigs, and rabbits) } \\
\text { 1-Low capacity: Sufficient for self-consumption, or large livestock } \leq 2 \\
\text { heads/ha (cattle, sheep, and goats) small livestock }<10 \text { heads (poultry, } \\
\text { pigs, and rabbits) } \\
\text { 0-No capacity: Not an activity in this land cover class }\end{array}$ \\
\hline Fodder & $\begin{array}{l}\text { Nutritional substance } \\
\text { for domestic animals } \\
\text { (Burkhard et al. 2009) } \\
\text { (Burkhard et al. 2014) }\end{array}$ & $\begin{array}{l}\text { Grasslands, } \\
\text { pastures, } \\
\text { agroforestry, } \\
\text { marshlands } \\
\text { (Burkhard et } \\
\text { al. 2009) } \\
\text { (Burkhard et } \\
\text { al. 2014) }\end{array}$ & $\begin{array}{l}\text { Harvested fodder crops: } \\
\mathrm{t} / \mathrm{ha} / \mathrm{yr} \text {; kJ/ha/yr } \\
\text { Indicators } \\
\text { Qualitative } \\
\text { Land cover class can } \\
\text { provide fodder for all } \\
\text { livestock in } \\
\text { agroecosystem } \\
\text { Quantitative } \\
\text { t/ha when data is } \\
\text { available } \\
\text { (Burkhard et al. 2009) } \\
\text { (Burkhardet al. 2014) }\end{array}$ & $\begin{array}{l}\text { How capable is the land cover class of providing fodder? } \\
\text { Specific questions } \\
\text { How much fodder is produced (humid matter)? } \\
\text { How many animals can be fed? } \\
\text { Scale } \\
5 \text {-Very high capacity: Land cover class provides more than sufficient fodder } \\
\text { production (>20 t/yr) or grazing ( } 8 \text { sheep/ha or } 1 \text { cattle/ha) } \\
\text { 4-High capacity: Land cover class provides sufficient fodder production (15 } \\
\text { - } 20 \text { t/ha/yr) or grazing ( } 8 \text { sheep/ha or } \leq 1 \text { cattle/ha) is an important } \\
\text { productive activity together with other activities } \\
\text { 3-Medium high capacity: Land cover class can produce fodder (10 - } 15 \\
\text { t/ha/yr) and sufficient fodder for livestock in FBA } \\
\text { 2-Relevant capacity: Land cover class can produce (5 - } 10 \mathrm{t} / \mathrm{ha} / \mathrm{yr} \text { ) or not } \\
\text { sufficient for livestock in FBA, some fodder is bought or collected outside } \\
\text { the FBA or fodder is a sub-product from horticulture }(5-10 \mathrm{t} / \mathrm{ha} / \mathrm{yr} \text { ) } \\
\text { 1-Low capacity: Land cover class can produce (<than } 5 \mathrm{t} / \mathrm{ha} / \mathrm{yr} \text { ) or not }\end{array}$ \\
\hline
\end{tabular}




\section{Landscape Online}

LANDSCAPE ONLINE 64:1- 48(2018), DOI 10.3097/LO.201864

Page 30

\begin{tabular}{|c|c|c|c|c|}
\hline & & & & $\begin{array}{l}\text { sufficient for livestock in FBA, regularly bought or collected elsewhere, or } \\
\text { fodder is a sub-product from horticulture }(<5 \mathrm{t} / \mathrm{ha} / \mathrm{yr}) \\
\text { 0-No capacity: Not an activity in this land cover class }\end{array}$ \\
\hline $\begin{array}{l}\text { Biochemical / medicine } \\
\text { (Genetic material from } \\
\text { Biota) }\end{array}$ & $\begin{array}{l}\text { Natural product } \\
\text { usable as } \\
\text { biochemical, } \\
\text { medicine, and/or } \\
\text { cosmetics } \\
\text { (Burkhard et al. 2014) }\end{array}$ & $\begin{array}{l}\text { Forests and } \\
\text { gardens } \\
\text { (Burkhard et } \\
\text { al. 2014) }\end{array}$ & $\begin{array}{l}\text { Yield of respective } \\
\text { products per year } \\
\text { Indicators } \\
\text { Qualitative } \\
\text { Importance of } \\
\text { biochemical medicine } \\
\text { production in land cover } \\
\text { class and degree of } \\
\text { sufficiency for demand in } \\
\text { FBA } \\
\text { (Burkhard et al. 2014) }\end{array}$ & $\begin{array}{l}\text { How capable is the land cover class of providing biochemicals/medicine? } \\
\text { Specific questions } \\
\text { How many types of biochemical/medicine can the land cover class } \\
\text { provide? } \\
\text { Do you use medicinal plants from this area? How many? } \\
\text { Is it an important economic activity? How important is the activity for your } \\
\text { income? } \\
\text { Scale } \\
\text { 5-Very high capacity: Biochemical medicine production is the main } \\
\text { productive activity (> } 60 \text { plant species/ha) or land cover class can provide } \\
\text { more plants than what is required by the community; some are sold } \\
\text { 4-High capacity: Biochemical medicine production ( } 45 \text {-60 plant species } \\
\text { /ha) or land cover class can provide all medicinal plants required by the } \\
\text { community } \\
\text { 3-Medium high capacity: Biochemical medicine production (30 - } 45 \text { plant } \\
\text { species/ha) or land cover class can provide most medicinal plants required } \\
\text { by the community } \\
\text { 2-Relevant capacity: Biochemical medicine production (15 - } 30 \text { plant } \\
\text { species/ha) or land cover class can provide some medicinal plants; some } \\
\text { may be bought or collected outside the FBA } \\
\text { 1-Low capacity: Biochemical medicine production (< } 15 \text { plant species/ha) }\end{array}$ \\
\hline
\end{tabular}




\begin{tabular}{|c|c|c|c|c|}
\hline & & & & $\begin{array}{l}\text { or very little biochemical medicine, not sufficient for own use. Must be } \\
\text { purchased } \\
\text { 0-No capacity: Not an activity in this land cover class }\end{array}$ \\
\hline \multicolumn{5}{|c|}{$\begin{array}{l}\text { DIVISION: MATERIALS (Haines-Young \& Potschin, 2013) } \\
\text { GROUP: BIOMASS }\end{array}$} \\
\hline Seeds & $\begin{array}{l}\text { Pool of genetic diversity } \\
\text { (seeds) needed to support } \\
\text { both natural and semi- } \\
\text { natural land cover classes } \\
\text { (Garbach et al. 2014) }\end{array}$ & $\begin{array}{l}\text { Agricultural } \\
\text { fields and } \\
\text { natural } \\
\text { vegetation }\end{array}$ & $\begin{array}{l}\text { Harvested seeds: } \\
\text { t/ha/yr } \\
\text { Indicators } \\
\text { Quantitative } \\
\text { Approximate \% of seeds } \\
\text { that are produced within } \\
\text { the land cover class for } \\
\text { replanting in the FBA }\end{array}$ & $\begin{array}{l}\text { Does the land cover class provide genetic resources for its regeneration? } \\
\text { Specific questions } \\
\text { Do you produce seeds? How much in kg and form which species? } \\
\text { How often do you buy seeds? } \\
\text { How much do you buy in kg and which species? } \\
\text { Where do you buy your seeds? } \\
\text { Scale } \\
5 \text {-Very high capacity: Land cover class is closed multi-layered trees with } \\
\text { natural regeneration (100\% of plants that grow in the land cover class } \\
\text { come from it) } \\
\text { 4-High capacity: Land cover class produces between } 75 \text { - } 100 \% \text { of the } \\
\text { required seeds or semi-natural vegetation-closed to open general trees } \\
\text { with closed to open shrubs } \\
\text { 3-Medium high capacity: Land cover class produces between } 50 \text { - } 75 \% \text { of } \\
\text { the required seeds or semi-natural vegetation-open to sparse trees with } \\
\text { open to sparse shrubs or herbaceous plants } \\
\text { 2-Relevant capacity: Land cover class produces between } 25 \text { - } 50 \% \text { of the } \\
\text { required seeds, tree plantation (hedge) with spontaneous regeneration, } \\
\text { grassland for grazing or fallow > } 1 \text { year }\end{array}$ \\
\hline
\end{tabular}




\section{Landscape Online}

LANDSCAPE ONLINE 64:1- 48(2018), DOI 10.3097/LO.201864

Page 32

\begin{tabular}{|c|c|c|c|c|}
\hline & & & & $\begin{array}{l}\text { 1-Low capacity: Land cover class produces between } 25 \% \text { of the required } \\
\text { seeds, tree plantation (hedge) with little spontaneous regeneration or } \\
\text { fallow < } 1 \text { year } \\
0 \text {-No capacity: No seed production in the land cover class }\end{array}$ \\
\hline $\begin{array}{l}\text { Timber (or other } \\
\text { construction } \\
\text { materials) }\end{array}$ & $\begin{array}{l}\text { Wood usable for human } \\
\text { purposes (e.g. Construction) } \\
\text { (Burkhard et al. 2014) }\end{array}$ & \begin{tabular}{|l|} 
Forests, \\
silvicultural \\
areas, \\
agroforestry \\
(Burkhard et \\
al. 2014)
\end{tabular} & $\begin{array}{l}\text { Harvested wood: } \\
\mathrm{m}^{3} / \text { region} / \mathrm{yr} \\
\text { Indicators } \\
\text { Qualitative } \\
\text { Importance of timber } \\
\text { production in land cover } \\
\text { class or sufficiency for } \\
\text { demand in FBA } \\
\text { (Burkhard et al. 2014) }\end{array}$ & $\begin{array}{l}\text { How capable is the land cover class of providing timber? } \\
\text { Specific questions } \\
\text { How much timber is harvested? } \\
\text { Do you sell (\% of income from timber) or buy timber? } \\
\text { Scale } \\
\text { 5-Very high capacity: Timber production is the main productive and } \\
\text { commercial activity of the land cover class } \\
\text { 4-High capacity: Timber production is a very important productive and } \\
\text { commercial activity of land cover class } \\
\text { 3-Medium high capacity: Timber production in land cover class is sufficient } \\
\text { for own use within the FBA, some may be sold } \\
\text { 2-Relevant capacity: Timber production in the land cover class is sufficient } \\
\text { for own consumption within the FBA, no timber is sold } \\
\text { 1-Low capacity: Timber production in land coverclass is not sufficient for } \\
\text { own use; it is purchased when needed } \\
\text { 0-No capacity: Not an activity in this land cover class }\end{array}$ \\
\hline
\end{tabular}




\section{Landscape Online}

LANDSCAPE ONLINE 64:1- 48(2018), DOI 10.3097/LO.201864

Page 33

\begin{tabular}{|c|c|c|c|c|}
\hline $\begin{array}{l}\text { DIVISION: ENERGY (Haine } \\
\text { GROUP: BIOMASS }\end{array}$ & s-Young \& Potschin, 20 & & & \\
\hline $\begin{array}{l}\text { Wood fuel (other energy } \\
\text { sources) }\end{array}$ & $\begin{array}{l}\text { Wood suitable for } \\
\text { energy conversion } \\
\text { and/or heat } \\
\text { production (Burkhard } \\
\text { et al. 2014) }\end{array}$ & $\begin{array}{l}\text { Forests, } \\
\text { hedgerows, } \\
\text { agroforestry } \\
\text { (Burkhard et } \\
\text { al. 2014) }\end{array}$ & $\begin{array}{l}\text { Harvested wood fuel: } \\
\mathrm{m}^{3} / \text { region/yr or } \mathrm{kg} / \mathrm{day} \\
\text { Indicators } \\
\text { Qualitative } \\
\text { Importance of wood fuel } \\
\text { production or sufficiency } \\
\text { for the demand in the FBA } \\
\text { (Burkhard et al. 2014) }\end{array}$ & $\begin{array}{l}\text { How capable is the land cover classof providing wood fuel? } \\
\text { Specific question } \\
\text { Is wood fuel production an activity in this land cover class type? } \\
\text { How much is produced and is it sufficient for your own consumption? } \\
\text { Scale } \\
\text { 5-Very high capacity: Wood fuel production is the main productive activity } \\
\text { of land cover class and most of it sold } \\
\text { 4-High capacity: Wood fuel production is an important productive activity } \\
\text { of the land cover class and most of it sold } \\
\text { 3-Medium high capacity: Wood fuel production is sufficient for own } \\
\text { consumption, some may be sold } \\
\text { 2-Relevant capacity: Wood fuel production is sufficient for own } \\
\text { consumption } \\
\text { 1-Low capacity: Wood fuel production is not sufficient for own } \\
\text { consumption; wood fuel or other sources of energy are purchased } \\
\text { 0-No capacity: Wood fuel production is not an activity in this land cover } \\
\text { class }\end{array}$ \\
\hline
\end{tabular}




\section{Landscape Online}

LANDSCAPE ONLINE 64:1- 48(2018), DOI 10.3097/LO.201864

Page 34

\begin{tabular}{|c|c|c|c|c|}
\hline \multicolumn{5}{|c|}{$\begin{array}{l}\text { SECTION: PROVISIONING SERVICES } \\
\text { DIVISION: MATERIALS (Haines-Young \& Potschin, 2013) } \\
\text { Group: Water }\end{array}$} \\
\hline Freshwater & $\begin{array}{l}\text { Water available for } \\
\text { drinking, irrigation, or } \\
\text { industrial use } \\
\text { (Burkhard et al. 2014) }\end{array}$ & $\begin{array}{l}\text { Rainwater } \\
\text { harvesting } \\
\text { system }\end{array}$ & $\begin{array}{l}\text { Rainwater harvested: } \\
\mathrm{L} / \text { region/yr; } \mathrm{m}^{3} / \text { region/yr } \\
\text { Indicators } \\
\text { Qualitative } \\
\text { Amount of water demand } \\
\text { of the FBA that is covered } \\
\text { by freshwater harvested } \\
\text { in the land cover }\end{array}$ & $\begin{array}{l}\text { How much freshwater (irrigation or drinking) can the land cover class } \\
\text { provide? } \\
\text { Specific questions } \\
\text { Do you harvest freshwater for irrigation (rainwater or springs)? How } \\
\text { much? } \\
\text { Scale } \\
\text { 5-Very high capacity: The land cover class can provide sufficient water for } \\
\text { the FBA that relies only on rainwater harvesting } \\
\text { 4-High capacity: The land cover class can provide water for the FBA that } \\
\text { relies mostly on harvested rainwater } \\
\text { 3-Medium high capacity: The land cover class can provide water for the } \\
\text { FBA that relies half on harvested rainwater and the rest from boreholes, } \\
\text { river water, or public water system } \\
\text { 2-Relevant capacity: Most of the water comes from boreholes, river water, } \\
\text { or public water system; only some rainwater is harvested } \\
\text { 1-Low capacity: Very little water is rainwater harvested for irrigation or } \\
\text { livestock } \\
\text { 0-No capacity: Not an activity in this land cover class }\end{array}$ \\
\hline
\end{tabular}




\begin{tabular}{|c|c|c|c|c|}
\hline $\begin{array}{l}\text { DIVISION: MAINTENANCI } \\
\text { GROUP: ATMOSPHERIC C }\end{array}$ & ND MAINTENANCE SERV & IATE REGULAT & IDITIONS (Haines-You & otschin, 2013) \\
\hline Local climate regulation & $\begin{array}{l}\text { Changes in local } \\
\text { climate components } \\
\text { like wind, } \\
\text { precipitation, } \\
\text { temperature, } \\
\text { radiation due to land } \\
\text { cover class properties } \\
\text { (Burkhard et al. 2014) }\end{array}$ & \begin{tabular}{|l} 
Forests, \\
wetlands, \\
lakes, oceans \\
(urban) green \\
areas, \\
agroforestry, \\
hedges \\
(Burkhard et \\
al. 2014)
\end{tabular} & $\begin{array}{l}\text { Temperature amplitudes } \\
\text { (k); precipitation, wind, or } \\
\text { evapotranspiration } \\
\text { deviation from } \\
\text { surrounding areas (\%) } \\
\text { Indicators } \\
\text { Qualitative } \\
\text { Perception of local } \\
\text { climate in the land cover } \\
\text { class as compared to } \\
\text { surrounding areas } \\
\text { (Burkhard et al. 2014) }\end{array}$ & $\begin{array}{l}\text { Can the land cover class generate better local climate? } \\
\text { Specific questions } \\
\text { Is temperature or wind in this land cover class different from surrounding } \\
\text { areas? } \\
\text { Scale } \\
\text { 5-Very high capacity: Local climate in the land cover class is much better } \\
\text { than in surrounding areas (less warm, less windy, or more humid) or land } \\
\text { cover class is closed multi-layered trees (broad-leaved evergreen) } \\
\text { 4-High capacity: Local climate in the land cover class is better than in } \\
\text { surrounding areas (less warm, less windy, more humid) or land cover class } \\
\text { is closed trees with shrubs } \\
\text { 3- Medium high capacity: Local climate in the land cover class is better } \\
\text { than in surrounding areas (less warm, less windy, more humid) or closed to } \\
\text { open general trees with shrubs } \\
\text { 2-Relevant capacity: Local climate in the land cover class is a little better } \\
\text { that in surrounding areas (less warm, less windy, more humid) or open to } \\
\text { sparse trees with open to sparse shrubs (tree plantation with almost no } \\
\text { shrubs) } \\
\text { 1-Low capacity: Local climate in the land cover class is the same as in } \\
\text { surrounding areas; land cover class is very small (hedge with trees) or } \\
\text { sparse trees with open shrubs or closed to very open herbaceous }\end{array}$ \\
\hline
\end{tabular}




\section{Landscape Online}

LANDSCAPE ONLINE 64:1- 48(2018), DOI 10.3097/LO.201864

Page 36

\begin{tabular}{|c|c|c|c|c|}
\hline & & & & $\begin{array}{l}\text { 0-No capacity: Local climate in the land cover class is worse than in } \\
\text { surrounding areas (warmer, windier, drier) or land cover class is bare soil }\end{array}$ \\
\hline $\begin{array}{l}\text { Global climate } \\
\text { regulation }\end{array}$ & $\begin{array}{l}\text { Long-term storage of } \\
\text { potential greenhouse } \\
\text { gases in land cover } \\
\text { class (Burkhard et al. } \\
2014 \text { ) }\end{array}$ & $\begin{array}{l}\text { Soils and } \\
\text { forest } \\
\text { (standing } \\
\text { biomass) } \\
\text { (Burkhard et } \\
\text { al. 2014) }\end{array}$ & $\begin{array}{l}\text { Amount of carbon dioxide } \\
\text { taken up by vegetation, } \\
\text { soils, and marine system: } \\
\mathrm{t} \mathrm{CO}_{2} / \mathrm{ha} / \mathrm{yr} \\
\text { Amount of practices that } \\
\text { promote GHG capture in } \\
\text { each land cover class, } \\
\text { capture as a proxy to the } \\
\text { amount of GHG capture } \\
\text { of the land cover class. } \\
\text { For natural and semi- } \\
\text { natural vegetation rate } \\
\text { qualitatively according to } \\
\text { vegetation cover } \\
\text { (FAO, 2013) } \\
\text { Indicators } \\
\text { Qualitative } \\
\text { 1-Amount of GHG } \\
\text { mitigation practices } \\
\text { implemented, or } \\
\text { 2-Type of natural and }\end{array}$ & $\begin{array}{l}\text { Can the land cover class contribute to global climate regulation? } \\
\text { Specific questions } \\
\text { Which of the mentioned practices do you implement? } \\
\text { Scale } \\
\text { 5-Very high capacity: Implements all recommended practices (FAO 2013) } \\
\text { plus additional innovations; or land cover class is closed multi-layered trees } \\
\text { 4-High capacity: Implements all recommended practices; or land cover } \\
\text { class is closed trees with shrubs } \\
\text { 3-Medium high capacity: Implements more that } 80 \% \text { of recommended } \\
\text { practices; or land cover class is closed to open general trees with shrubs } \\
\text { 2-Relevant capacity: Implements } 50 \text { - } 80 \% \text { of recommended practices or } \\
\text { land cover class is open trees with closed to open shrubs (tree plantation } \\
\text { with almost no shrubs) } \\
\text { 1-Low capacity: Implements less than } 50 \% \text { of recommended practices, or } \\
\text { land cover class is sparse trees with open shrubs or closed to very open } \\
\text { herbaceous } \\
\text { 0-No capacity: Practices one of the non-recommended practices or land } \\
\text { cover class is bare soil } \\
\text { Recommended GHG Mitigation practices (FAO 2013) } \\
\text { Cropland management } \\
\text { 1-Soil fertility management with organic materials and improved fertilizer }\end{array}$ \\
\hline
\end{tabular}




\section{Landscape Online}

LANDSCAPE ONLINE 64:1- 48(2018), DOI 10.3097/LO.201864

Page 37

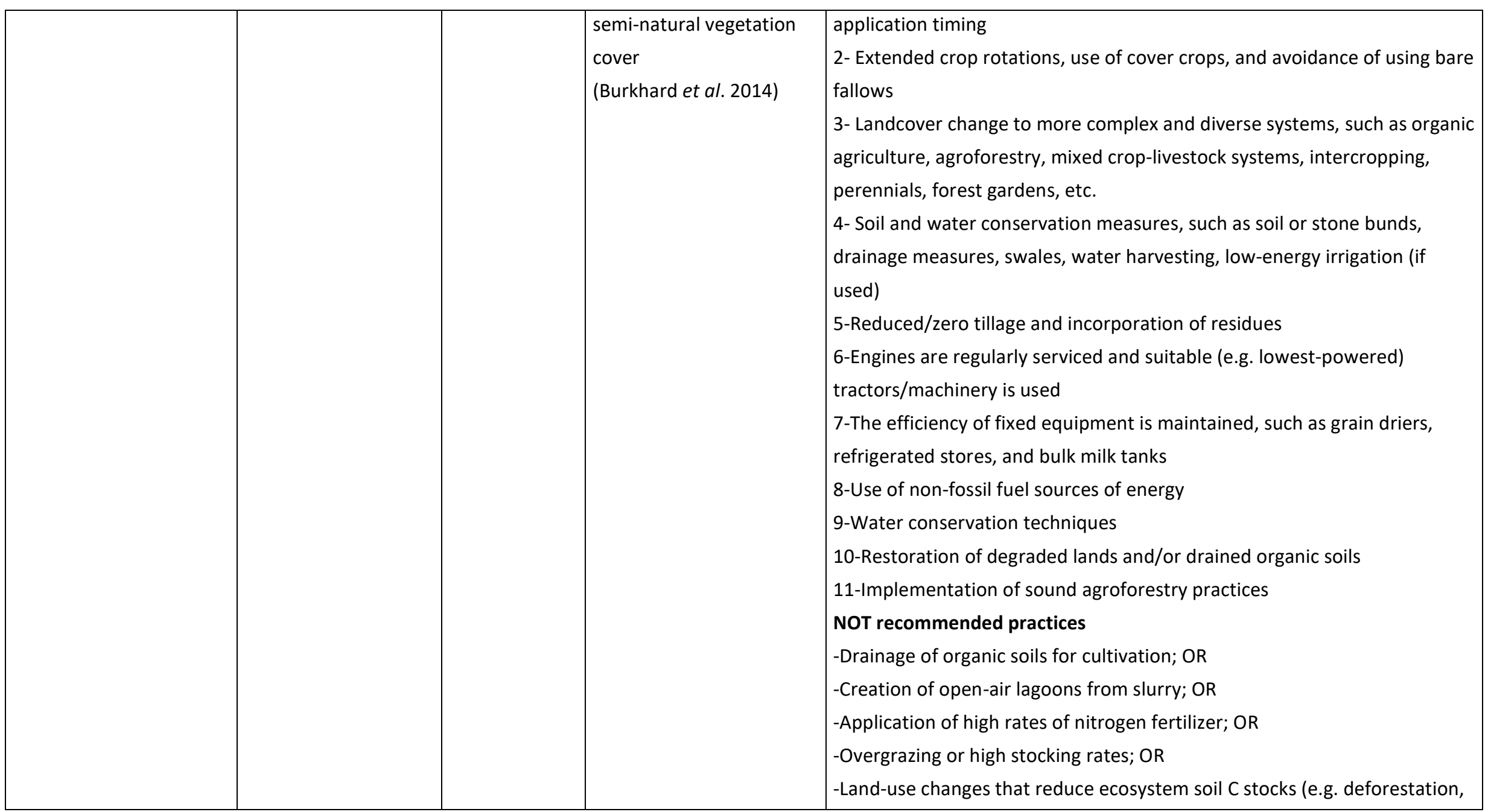




\section{Landscape Online}

LANDSCAPE ONLINE 64:1- 48(2018), DOI 10.3097/LO.201864

Page 38

\begin{tabular}{|c|c|c|c|c|}
\hline & & & & $\begin{array}{l}\text { ploughing long term } \\
\text { grasslands); OR } \\
\text {-Use of large-scale annual monocultures (more than 50ha); OR } \\
\text {-Practice of slash-and-burn or burning of residues }\end{array}$ \\
\hline \multicolumn{5}{|c|}{ DIVISION: MEDIATION OF FLOWS (Haines-Young and Potschin, 2013) } \\
\hline Erosion regulation & $\begin{array}{l}\text { Soil retention and the } \\
\text { ability to prevent and } \\
\text { mitigate soil erosion } \\
\text { and landslides } \\
\text { (Burkhard et al. 2014) }\end{array}$ & $\begin{array}{l}\text { Forest hedges, } \\
\text { groves around } \\
\text { and between } \\
\text { acre fields, } \\
\text { pastures, and } \\
\text { grasslands } \\
\text { (Burkhard et } \\
\text { al. 2014) }\end{array}$ & $\begin{array}{l}\text { Soil retained or sediment } \\
\text { captured } \\
\text { (Burkhard et al. 2014). } \\
\text { Cover crops and perennial } \\
\text { crops } \\
\text { (Garbach et al. 2014). Due } \\
\text { to the complexity of } \\
\text { assessing the amount of } \\
\text { soil retained, visual } \\
\text { assessment of capacity of } \\
\text { land cover class to } \\
\text { provide erosion control. } \\
\text { Existence or not of visual } \\
\text { soil erosion problems } \\
\text { Indicators } \\
\text { Qualitative } \\
\text { Existence or not of visual } \\
\text { soil erosion problems }\end{array}$ & $\begin{array}{l}\text { How capable is the land cover class of regulating soil erosion? } \\
\text { Specific questions } \\
\text { Are there erosion problems? } \\
\text { How is soil erosion controlled? How much time in the year is the soil } \\
\text { uncovered? } \\
\text { Are there strong winds? } \\
\text { Scales } \\
\text { Adapted scale of Visual Soil Assessment FAO (2008p. 23). } \\
\text { 5-Very high capacity: No signs of wind or water erosion, or land cover class } \\
\text { is closed multi-layered trees (at least } 3 \text { layers) } \\
\text { 4-High capacity: No signs of wind or water erosion, permanent vegetation } \\
\text { cover, well-structured trees and crops (at least } 2 \text { layers), or land cover class } \\
\text { is closed trees with shrubs } \\
\text { 3- Medium high capacity: No signs of wind or water erosion, partial } \\
\text { vegetation cover or land cover class is closed to open general trees with } \\
\text { shrubs } \\
\text { 2-Relevant capacity: Wind erosion is not a concern; only small dust plumes } \\
\text { in windy days, most eroded material is contained in the field. Crops only (1 }\end{array}$ \\
\hline
\end{tabular}




\begin{tabular}{|c|c|c|c|c|}
\hline & & & using VSA & $\begin{array}{l}\text { layer) with no visual signs of water erosion } \\
\text { 1- Low capacity: Wind erosion is of moderate concern, significant dust } \\
\text { plumes in windy days. Considerable amount is blown out of the field. Crops } \\
\text { only (1 layer).Water erosion is a moderate concern, with a significant } \\
\text { amount of rilling and sheet erosion } \\
\text { 0-No capacity: Water erosion is a major concern with severe gullying, } \\
\text { rilling, and sheet erosion. Wind erosion is a major concern. Large dust } \\
\text { clouds can occur when cultivating on windy days and a substantial amount } \\
\text { can be lost from the field. Or, bare soil (e.g. from dirt roads) }\end{array}$ \\
\hline \multicolumn{5}{|c|}{$\begin{array}{l}\text { DIVISION: MAINTENANCE OF PHYSICAL, CHEMICAL, AND BIOLOGICAL CONDITIONS (Haines-Young \& Potschin, 2013) } \\
\text { GROUP: SOIL FORMATION AND COMPOSITION }\end{array}$} \\
\hline $\begin{array}{l}\text { Nutrient regulation } \\
\text { (decomposition and } \\
\text { fixing processes) }\end{array}$ & $\begin{array}{l}\text { Land cover class } \\
\text { ability to recycle } \\
\text { nutrients (e.g. } \\
\text { nitrogen, phosphorus, } \\
\text { potassium, etc.) } \\
\text { (Burkhard et al. 2014) }\end{array}$ & $\begin{array}{l}\text { Forests, } \\
\text { grasslands, } \\
\text { wetlands, } \\
\text { marshes, } \\
\text { waterbodies, } \\
\text { oceans } \\
\text { (Burkhard et } \\
\text { al. 2014) }\end{array}$ & $\begin{array}{l}\text { Nutrients available for } \\
\text { plant uptake (NPK) } \\
\mathrm{kg} / \mathrm{ha} / \mathrm{yr} \\
\text { Amount of excess } \\
\text { nutrients } \\
\mathrm{kg} / \mathrm{ha} / \mathrm{yr} \\
\text { Indicators } \\
\text { Qualitative } \\
\text { 1-Soils fertility using } \\
\text { Visual Soil Assessment } \\
\text { (VSA), OR } \\
\text { 2-Perception of soil } \\
\text { fertility }\end{array}$ & $\begin{array}{l}\text { How capable is the land cover class of maintaining soil fertility? } \\
\text { Specific questions } \\
\text { How has your soil fertility changed in the last five years? } \\
\text { Scale } \\
5 \text {-Very high capacity: Fertility has increased in the last five years and there } \\
\text { is no need for external inputs for production; or the land cover class is } \\
\text { natural or semi-natural terrestrial vegetation } \\
\text { 4-High capacity: Fertility has increased in the last } 5 \text { years, sporadic use of } \\
\text { external inputs and rotation to maintain soil fertility, or land cover class is a } \\
\text { tree plantation ( }>5 \text { years) and/or long term fallow ( }>5 \text { year) } \\
\text { 3-Medium high capacity: Fertility has increased and relies on external } \\
\text { inputs increase soil fertility, or land cover class is a tree plantation }(<5 \\
\text { years) and/or long-term fallow ( }<5 \text { year) }\end{array}$ \\
\hline
\end{tabular}




\section{Landscape Online}

LANDSCAPE ONLINE 64:1- 48(2018), DOI 10.3097/LO.201864

Page 40

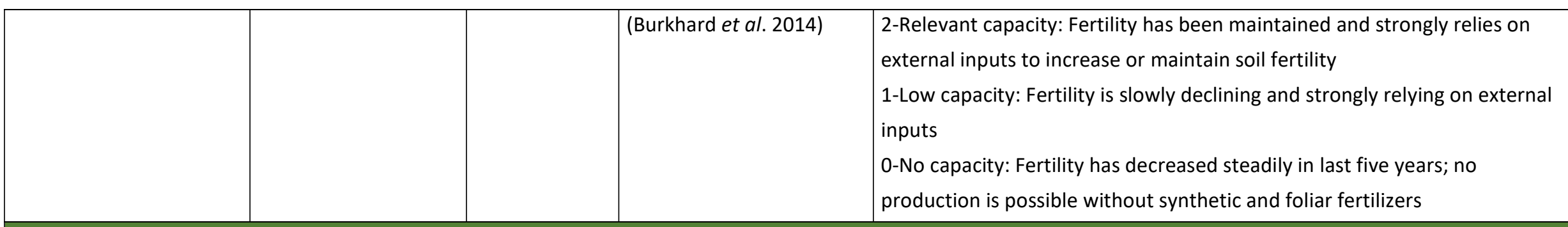

DIVISION: MAINTENANCE OF PHYSICAL, CHEMICAL, AND BIOLOGICAL CONDITIONS (Haines-Young \& Potschin, 2013)

GROUP: WATER CONDITIONS

\begin{tabular}{|c|c|c|c|c|}
\hline $\begin{array}{l}\text { Water purification } \\
\text { (quality) }\end{array}$ & $\begin{array}{l}\text { Land cover ability to } \\
\text { purify water (e.g. } \\
\text { sediments, pollutants, } \\
\text { nutrients, pesticides, } \\
\text { disease-causing } \\
\text { microbes and } \\
\text { pathogens) } \\
\text { (Burkhard et al. 2014) }\end{array}$ & $\begin{array}{l}\text { Waterbodies, } \\
\text { aquatic flora, } \\
\text { riparian strips, } \\
\text { filtrating soils, } \\
\text { forest, } \\
\text { wetlands, } \\
\text { grasslands } \\
\text { (Burkhard et } \\
\text { al. 2014) }\end{array}$ & $\begin{array}{l}\text { Elements removed from } \\
\text { water } \\
\mathrm{kg} / \mathrm{m}^{3} / \mathrm{yr} \\
\text { Water quality standards } \\
\text { amplitude } \\
\mathrm{ppb} ; \mathrm{mg} / \mathrm{l} \\
\text { (Burkhard et al. 2014). } \\
\text { The existence or not of } \\
\text { activities that prevent } \\
\text { water pollution within the } \\
\text { land cover class } \\
\text { FAO, 2013 } \\
\text { Indicators } \\
\text { Qualitative } \\
\text { 1-Amount of non- }\end{array}$ & $\begin{array}{l}\text { How capable is the land cover class of regulating water quality? } \\
\text { Specific questions } \\
\text { How many of the mentioned practices do you use? } \\
\text { Land Management } \\
\text { 1-Land use and land cover class change to more complex and diverse } \\
\text { systems with better soil coverage, such as agroforestry, organic } \\
\text { management, mixed crop-livestock systems, mixed rice-fish } \\
\text { systems, intercropping, perennials, poly-cultures, forest gardens, etc. } \\
\text { 2-Adoption of no-spray buffer zones } \\
\text { 3-Conservation tillage practices. } \\
\text { 4-Non-use of highly hazardous chemicals, persistent organic pollutants, } \\
\text { and those having potential adverse effects on aquatic life, including copper } \\
\text { sulfite, glyphosate, atrazine, 2,4-D, carbonyl, malathion, etc.; AND/OR no } \\
\text { visible signs of eutrophication algae bloom in waterbodies } \\
\text { 5-Protecting hedgerows (min. 1-metre-widearound the whole farm), water } \\
\text { courses, wells, boreholes, and springs by not cultivating adjacent to them }\end{array}$ \\
\hline
\end{tabular}




\section{Landscape Online}

LANDSCAPE ONLINE 64:1- 48(2018), DOI 10.3097/LO.201864

Page 41

\begin{tabular}{|c|c|c|c|c|}
\hline & & & $\begin{array}{l}\text { polluting practices } \\
\text { 2-For semi-natural land } \\
\text { cover classes assess } \\
\text { according to vegetation } \\
\text { cover }\end{array}$ & $\begin{array}{l}\text { or leaving at least (local regulations) or } 3 \text { metres of distance with buffer } \\
\text { strips } \\
\text { Processing and marketing } \\
\text { 1-Implementation of good agricultural and manufacturing practices; AND } \\
\text { 2-Separated or recovered wastewater; AND } \\
\text { 3-Wastewater treatment, such as centrifugation, evaporation, filtration, } \\
\text { flotation, gravity separation, membrane systems, conversion of } \\
\text { constituents, biological treatment, etc. } \\
\text { Not recommended practices } \\
\text { 1-Application of pesticides that are not allowed by law, highly hazardous } \\
\text { chemicals, persistent organic pollutants, and those having potential } \\
\text { adverse effects on aquatic life; OR } \\
\text { 2-Absence of any buffer zones to protect surface water, violation of water } \\
\text { protection areas }\end{array}$ \\
\hline \multicolumn{5}{|c|}{ DIVISION: MEDIATION OF FLOWS (Haines-Young \& Potschin, 2013) } \\
\hline $\begin{array}{l}\text { Water regulation } \\
\text { (Quantity) }\end{array}$ & $\begin{array}{l}\text { Water cycle feature } \\
\text { maintenance (e.g. } \\
\text { water storage and } \\
\text { buffer, natural } \\
\text { drainage, irrigation, } \\
\text { drought prevention) } \\
\text { (Burkhard et al. 2014) }\end{array}$ & $\begin{array}{l}\text { Waterbodies, } \\
\text { aquatic flora, } \\
\text { riparian strips, } \\
\text { filtrating soils, } \\
\text { forest, } \\
\text { wetlands, } \\
\text { grasslands } \\
\text { (Burkhard et }\end{array}$ & $\begin{array}{l}\text { Water released for } \\
\text { hydrological process use } \\
\text { e.g. plant or animal } \\
\text { uptake soil processes } \\
\mathrm{m}^{3} / \mathrm{ha} / \mathrm{yr} \\
\text { available water content } \\
\text { v\% } \\
\text { amount of excess water }\end{array}$ & $\begin{array}{l}\text { How capable is the land cover classof regulating water quantity? } \\
\text { Specific questions } \\
\text { How many of the mentioned practices do you use? } \\
\text { Scale } \\
5 \text {-Very high capacity: Land cover class regulates water quantity very well; } \\
\text { five recommended practices plus others are implemented, or vegetation is } \\
\text { closed multi-layered trees (broad-leaved evergreen) or natural water } \\
\text { reservoir }\end{array}$ \\
\hline
\end{tabular}




\section{Landscape Online}

LANDSCAPE ONLINE 64:1- 48(2018), DOI 10.3097/LO.201864

Page 42

\begin{tabular}{|c|c|c|c|}
\hline & al. 2014) & $\begin{array}{l}\mathrm{m}^{3} / \mathrm{ha} / \mathrm{yr} \\
\text { (Burkhard et al. 2014) } \\
\text { Indicators } \\
\text { Qualitative } \\
\text { 1-Number of best } \\
\text { practices for water } \\
\text { conservation } \\
\text { implemented SAFA (FAO, } \\
\text { 2013b) } \\
\text { 2-For semi-natural land } \\
\text { cover classes assess } \\
\text { according to vegetation } \\
\text { cover }\end{array}$ & $\begin{array}{l}\text { 4-High capacity: Land cover class regulates water quantity (4 - } 5 \text { of the } \\
\text { recommended practices) well, or land cover class is closed to open trees } \\
\text { with closed shrubs or artificial water reservoir } \\
\text { 3-Medium high capacity: Land cover class regulates water quantity ( } 3 \text { - } 4 \text { of } \\
\text { the recommended practices);land cover class is open to sparse trees with } \\
\text { open shrubs } \\
\text { 2-Relevant capacity: Land cover class regulates water quantity (2 - } 3 \text { of the } \\
\text { recommended practices) or tree plantation with native trees } \\
\text { 1-Low capacity: Land cover class has low capacity to regulate water } \\
\text { quantity (1 - } 2 \text { of recommended practices) or land cover class tree } \\
\text { plantation with exotic trees (hedge) } \\
\text { 0-No capacity: Land cover class does not protect water resources } \\
\text { Land Management } \\
\text { 1-Mulching and tillage to break pore continuity and reduce water } \\
\text { evaporation from soils; } \\
\text { 2-Water harvesting and/or wastewater recycling } \\
\text { 3-Minimization of irrigation water, such as by use of efficient irrigation } \\
\text { technologies; (aspersion and drip irrigation) } \\
\text { 4-Agroforestry and/or maintaining vegetation along rivers or other } \\
\text { waterbodies. } \\
\text { 5-Breeding and selection of crop species and varieties, and of animal } \\
\text { species and breeds that are adapted to local climate and make efficient use } \\
\text { of water }\end{array}$ \\
\hline
\end{tabular}




\section{Landscape Online}

LANDSCAPE ONLINE 64:1- 48(2018), DOI 10.3097/LO.201864

Page 43

\begin{tabular}{|c|c|c|c|c|}
\hline & & & & $\begin{array}{l}\text { Processing and marketing } \\
\text {-Implementation of good manufacturing practices; AND } \\
\text {-Efficient water demanding technologies in processing are in place; AND } \\
\text {-Waste water recycling }\end{array}$ \\
\hline \multicolumn{5}{|c|}{$\begin{array}{l}\text { DIVISION: MAINTENANCE OF PHYSICAL, CHEMICAL, BIOLOGICAL CONDITIONS (Haines-Young \& Potschin, 2013) } \\
\text { GROUP: LIFECYCLE MAINTENANCE, HABITAT AND GENE POOL PROTECTION }\end{array}$} \\
\hline Pollination & $\begin{array}{l}\text { Bees, birds, bats } \\
\text { moths, flies, wind, } \\
\text { non-flying animals } \\
\text { contributing to pollen } \\
\text { transfer and } \\
\text { reproduction of } \\
\text { plants } \\
\text { (Burkhard et al. 2014) }\end{array}$ & $\begin{array}{l}\text { Gardens, fruit } \\
\text { plantations, } \\
\text { forest, } \\
\text { wetlands, } \\
\text { agricultural } \\
\text { areas } \\
\text { (Burkhard et } \\
\text { al. 2014) }\end{array}$ & \begin{tabular}{|l|} 
Amount of pollinated \\
plants \\
$\mathrm{n} / \mathrm{ha} / \mathrm{yr}, \mathrm{kg} / \mathrm{ha} / \mathrm{yr}$ \\
(Burkhard et al. 2014) \\
Indicators \\
Qualitative \\
Amount of pollinating \\
friendly practices \\
determined by FAO (2012) \\
that are implemented in \\
the land cover class \\
(Grieg-Gran \& Gemmill- \\
Herren 2012)
\end{tabular} & $\begin{array}{l}\text { How capable is the land cover class of enhancing pollination? } \\
\text { Scale } \\
\text { 5-Very high capacity: Land cover class strongly enhances pollination; five } \\
\text { recommended practices or more are implemented. Or vegetation is closed } \\
\text { multi-layered trees (broad-leaved evergreen) or natural water reservoir. } \\
\text { 4-High capacity: Land cover class well enhances pollination ( } 4 \text { - } 5 \text { of the } \\
\text { recommended practices) or land cover class is closed to open trees with } \\
\text { closed shrubs } \\
\text { 3-Medium high capacity: Land cover class enhances pollination ( } 3 \text { - } 4 \text { of the } \\
\text { recommended practices) or land cover class is open to sparse trees with } \\
\text { open to sparse shrubs } \\
\text { 2-Relevant capacity: Land cover class enhances pollination ( } 2 \text { - } 3 \text { of the } \\
\text { recommended practices) } \\
\text { 1-Low capacity: Land cover class has low capacity to enhance pollination (1 } \\
\text { - } 2 \text { of recommended practices) } \\
\text { 0-No capacity: Land cover class does not enhance pollination }\end{array}$ \\
\hline
\end{tabular}




\begin{tabular}{|c|c|c|c|c|}
\hline & & & & $\begin{array}{l}\text { Recommended practices } \\
\text { 1-Mixed cropping in time (rotation) or space (intercropping) } \\
\text { 2-Patches of non-crop vegetation and/or shade tree cultivation } \\
\text { 3-Flower-rich field margins buffer zones and permanent hedgerows and/or } \\
\text { selective weeding } \\
\text { 4-Use of NO pesticides or bee-friendly pesticides } \\
\text { 5-Introduced managed pollinators (beehives) }\end{array}$ \\
\hline \multicolumn{5}{|c|}{$\begin{array}{l}\text { DIVISION: MAINTENANCE OF PHYSICAL, CHEMICAL, BIOLOGICAL CONDITIONS (Haines-Young \& Potschin, 2013) } \\
\text { GROUP: PEST AND DISEASE CONTROL }\end{array}$} \\
\hline Biological control & $\begin{array}{l}\text { Land cover class } \\
\text { ability to control } \\
\text { pests and diseases, } \\
\text { due to genetic } \\
\text { variation of plants } \\
\text { and animals making } \\
\text { them less prone to } \\
\text { diseases and action of } \\
\text { predators and } \\
\text { parasites (Burkhard et } \\
\text { al. 2014) }\end{array}$ & \begin{tabular}{|l} 
Forests, \\
wetlands, \\
waterbodies, \\
gardens, \\
agricultural \\
areas \\
(Burkhard et \\
al. 2014)
\end{tabular} & $\begin{array}{l}\text { Estimating the service is } \\
\text { complex, hence estimate } \\
\text { the NO service by } \\
\text { counting the number of } \\
\text { pest and disease } \\
\text { outbreaks } n / h a / y r \\
\text { Plants and animals } \\
\text { damaged } \\
\text { Yield loss \%/yr } \\
\text { Indicators } \\
\text { Qualitative } \\
\text { Importance of pests and }\end{array}$ & $\begin{array}{l}\text { How capable is the land cover class of regulating pests and diseases? } \\
\text { Specific questions } \\
\text { How many pest and disease outbreaks in last } 5 \text { years? } \\
\text { How do you control them? } \\
\text { How important was the loss? } \\
\text { Scale } \\
5 \text {-Very high capacity: No pests or disease outbreaks in the last } 5 \text { years, the } \\
\text { notion of pests and diseases does not exist, therefore no efforts invested in } \\
\text { controlling pests and diseases, and no economic loss in last } 5 \text { years } \\
\text { 4-High capacity: Very few pests and diseases, controlled by hand; no inputs } \\
\text { (nether organic of non-organic) and no economic loss in last } 5 \text { years } \\
\text { 3- Medium high capacity: Sporadic pests and diseases, controlled with } \\
\text { organic products or by intercropping. } \\
\text { 2-Relevant capacity: Possible pests and diseases, controlled with organic } \\
\text { products, Integrated Pest Management (IPM), and/or synthetic products }\end{array}$ \\
\hline
\end{tabular}




\section{Landscape Online}

LANDSCAPE ONLINE 64:1- 48(2018), DOI 10.3097/LO.201864

Page 45

\begin{tabular}{|c|c|c|c|c|}
\hline & & & $\begin{array}{l}\text { diseases in the land cover } \\
\text { class } \\
\text { (Burkhard et al. 2014) }\end{array}$ & $\begin{array}{l}\text { and economic loss of up to } 20 \% \\
\text { 1-Low capacity: regular presence of pests and diseases, dependence on } \\
\text { IPM; agrochemicals for production and up to } 30 \% \text { loss if no use of } \\
\text { agrochemicals } \\
0 \text {-No capacity: Constant presence of pests and diseases, constant } \\
\text { application of agrochemicals hence important role in budget, and up to } \\
50 \% \text { of loss or more if no use of agrochemicals }\end{array}$ \\
\hline \multicolumn{5}{|c|}{ SECTION: CULTURAL SERVICES } \\
\hline \multicolumn{5}{|c|}{$\begin{array}{l}\text { DIVISION: PHYSICAL AND INTELLECTUAL INTERACTIONS WITH BIOTA, ECOSYSTEMS, AND LAND/SEASCAPES [ENVIRONMENTAL SETTINGS] (Haines-Young \& PotsChin } \\
\text { 2013) } \\
\text { GROUP: INTELLECTUAL AND REPRESENTATIVE INTERACTIONS }\end{array}$} \\
\hline Knowledge systems & $\begin{array}{l}\text { Land cover class } \\
\text { capacity to enhance } \\
\text { the creation and } \\
\text { sharing of new } \\
\text { knowledge (systems, } \\
\text { target, or } \\
\text { transformation } \\
\text { knowledge) }\end{array}$ & $\begin{array}{l}\text { Forests, } \\
\text { wetlands, } \\
\text { waterbodies, } \\
\text { gardens, } \\
\text { agricultural } \\
\text { areas }\end{array}$ & $\begin{array}{l}\text { Number of new } \\
\text { experiments (new } \\
\text { knowledge), number of } \\
\text { educational events, and } \\
\text { number of their users } \\
\text { (n/a) } \\
\text { Number and relative } \\
\text { importance of different } \\
\text { knowledge systems } \\
\text { (systems, target, or } \\
\text { transformation } \\
\text { knowledge) } \\
\text { Indicators }\end{array}$ & $\begin{array}{l}\text { Does the land cover class enhance the creation and sharing of knowledge? } \\
\text { Specific questions } \\
\text { Do you offer any educational activities in the farm? } \\
\text { What type of knowledge is shared? How many activities and participants } \\
\text { per year? } \\
\text { Do you experiment with new things? From whom did you learn what you } \\
\text { know? } \\
\text { Scale } \\
5 \text {-Very high capacity: New knowledge is constantly being created and } \\
\text { shared by experimenting with new techniques (systems knowledge), there } \\
\text { is a vision of a desired future (target knowledge), and there are } \\
\text { implementation actions for transformation (transformation knowledge). } \\
\text { We have many educational activities (>24/yr, average } 30 \text { participants) }\end{array}$ \\
\hline
\end{tabular}




\section{Landscape Online}

LANDSCAPE ONLINE 64:1- 48(2018), DOI 10.3097/LO.201864

Page 46

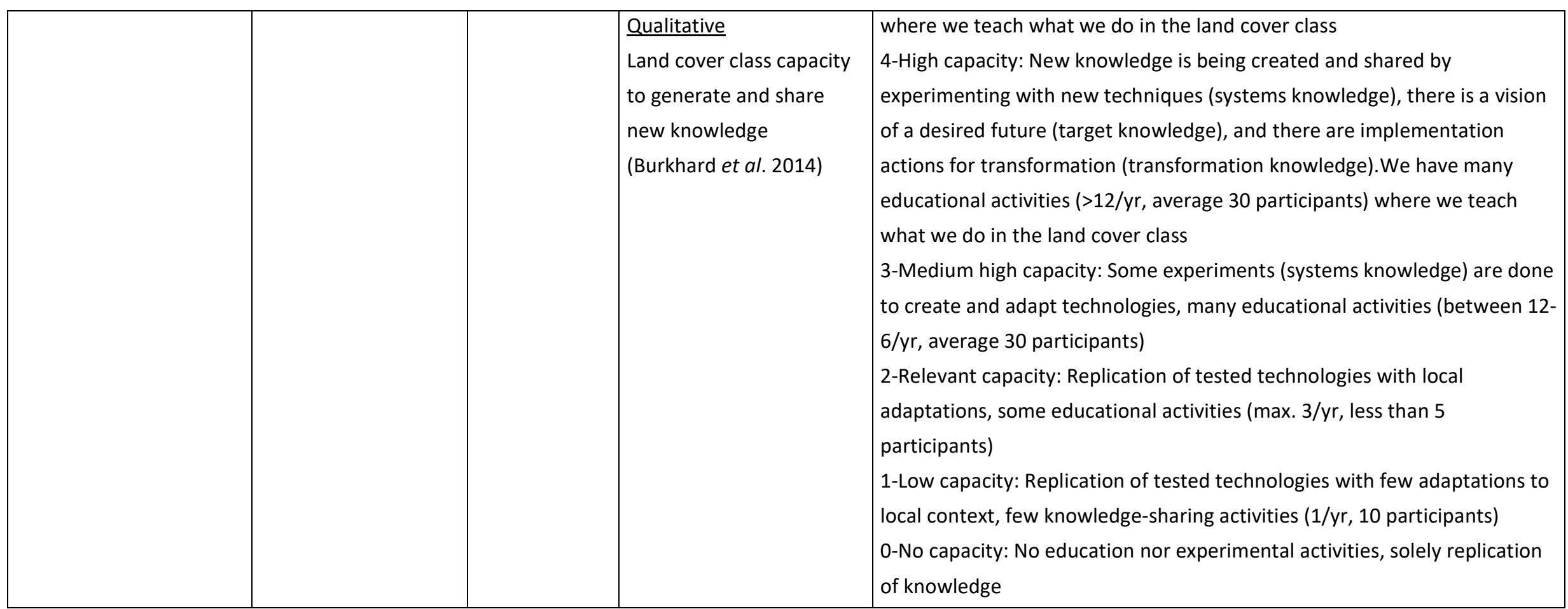




\section{Landscape Online}

LANDSCAPE ONLINE 64:1- 48(2018), DOI 10.3097/LO.201864

Page 47

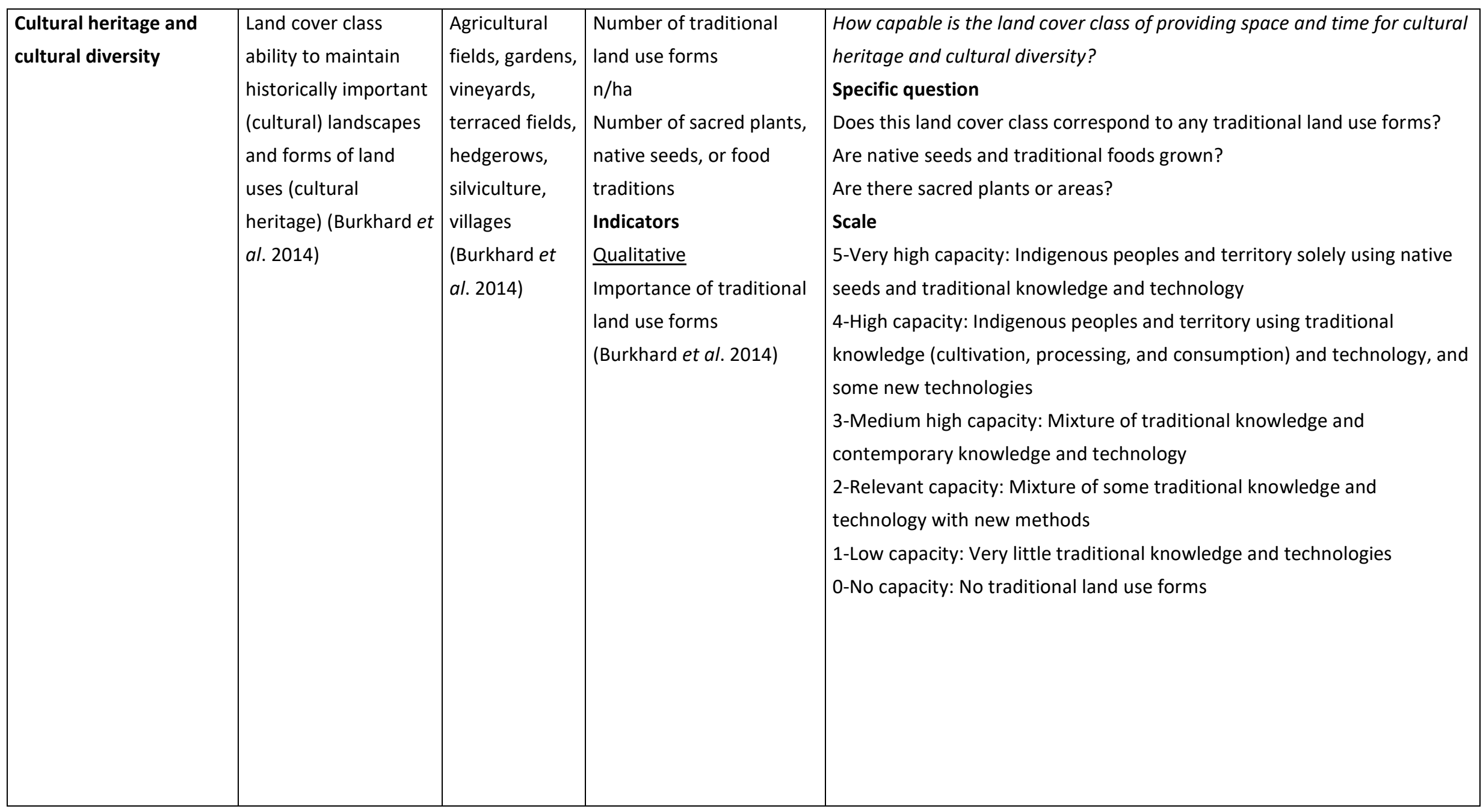




\section{Landscape Online}

LANDSCAPE ONLINE 64:1- 48(2018), DOI 10.3097/LO.201864

Page 48

\begin{tabular}{|c|c|c|c|c|}
\hline $\begin{array}{l}\text { SECTION: SUPPORTIN } \\
\text { Division: SUPPORTINC } \\
\text { Group: TERRESTRIAL }\end{array}$ & \multicolumn{3}{|c|}{$\begin{array}{l}\text { SECTION: SUPPORTING SERVICES } \\
\text { Division: SUPPORTING SERVICES }\end{array}$} & \\
\hline Biotic heterogeneity & $\begin{array}{l}\text { Diversity of natural } \\
\text { and semi-natural } \\
\text { vegetation and } \\
\text { agrobiodiversity. } \\
\text { Presence or absence } \\
\text { of selected species } \\
\text { (functional groups) } \\
\text { (Burkhard et al. 2009) }\end{array}$ & $\begin{array}{l}\text { All land cover } \\
\text { classes } \\
\text { (Burkhard et } \\
\text { al. 2009) }\end{array}$ & $\begin{array}{l}\text { Indicator species } \\
\text { (Burkhard et al. 2009) } \\
\text { Indicators } \\
\text { Quantitative } \\
\text { Standardized Shannon- } \\
\text { Weaver index } \\
\text { (Griffon 2008) }\end{array}$ & $\begin{array}{l}\text { How capable is the land cover class of enhancing biotic heterogeneity? } \\
\text { Specific questions } \\
\text { Which and how many crops and associated vegetation does each land } \\
\text { cover class contain? } \\
\text { Scale } \\
\text { 5-Very high diversity: Shannon index }>1 \\
\text { 4-High diversity: Shannon index between } 0.8 \text { - } 1 \\
\text { 3-Medium high diversity: Shannon index between } 0.6 \text { - } 0.8 \\
\text { 2-Relevant diversity: Shannon index between } 0.4 \text { - } 0.6 \\
\text { 1-Low diversity: Shannon index between } 0.2-0.4 \\
\text { 0-No diversity: Shannon index < } 0.2 \\
\text { Shannon index } \\
\text { To calculate the Shannon index for each land cover class: } \\
1 \text { Calcify the land cover class and calculate the area } \\
2 \text { Count the number of plants per area: } \\
\text {-For crop areas, in three randomly selected squares of } 1 \mathrm{~m} * 1 \mathrm{~m} \text { count the } \\
\text { number or crops per metre and estimate total crops per hectare } \\
\text {-For semi natural and natural vegetation, take threedistant randomly } \\
\text { selected areas that are the size of the highest shrub or tree (i.e. if the } \\
\text { highest tree is } 12 \mathrm{~m} \text { then make a sample plot of } 12 * 12 \mathrm{~m} \text { ) } \\
3 \text { Calculate the Shannon index as in Griffon (2008) }\end{array}$ \\
\hline
\end{tabular}

